\title{
QA/QC in Transport Infrastructures: Issues and Perspectives
}

\author{
Filippo G. Praticò \\ University Mediterranea at Reggio Calabria \\ Italy
}

\section{Introduction}

Transport infrastructures (road and highway networks, railways, terminal facilities, airports, mass transit systems, bicycle paths and pedestrian walkways, etc.) have significant impacts on the development of regional and national economies. However, the effectiveness of these impacts over the time has to be established based on the actual quality of all the pertaining components of the infrastructure asset (pavement, safety barriers, signals, illumination, embankment, drainage, etc.). Quality can be interpreted as the degree of excellence of a product or service, or as the degree to which a product or service satisfies the needs of a specific customer or, finally, as the degree to which a product or service conforms with a given requirement. In more detail, quality assurance (QA) refers to all those planned and systematic actions necessary to provide confidence that a product or facility will perform satisfactorily in service. At the same time, quality control (QC), also called process control, relates to those QA actions and considerations necessary to assess and adjust production and construction processes so as to control the level of quality being produced in the end product (Fig.1). Note that QA (which includes QC) is an infrastructure (e.g. highway) agency responsibility and involves all the process (planning, design, plan and specifications, construction, etc.), while QC is a producer-contractor responsibility which mainly affects construction. Furthermore, QC is not simply QA in construction, due to the fact that both independent assurance and acceptance procedures refer to QA in construction but they are NOT a part of QC. The entire QA/QC process includes: i) setting up the initial data collection or experimentation to determine typical parameters of current construction; ii) designing the acceptance plan itself, including selecting quality characteristics (and corresponding specification limits), statistical quality measure (and corresponding quality levels), buyer's and seller's risks, lot size, number of samples (sample size), specification and/or acceptance limits, and payment-adjustment provisions. As is well known (Burati et al, 2003), traditionally, highway specifications spelled out in detail the work that was to be done by the contractor under the form of materials and methods specifications (also called method specifications, recipe specifications, or prescriptive specifications). In this case, specifications direct the contractor to use specified materials in definite proportions and specific types of equipment and methods to place the material. On the contrary, end result specifications require the contractor to take the entire responsibility for supplying a product or an item of construction. 


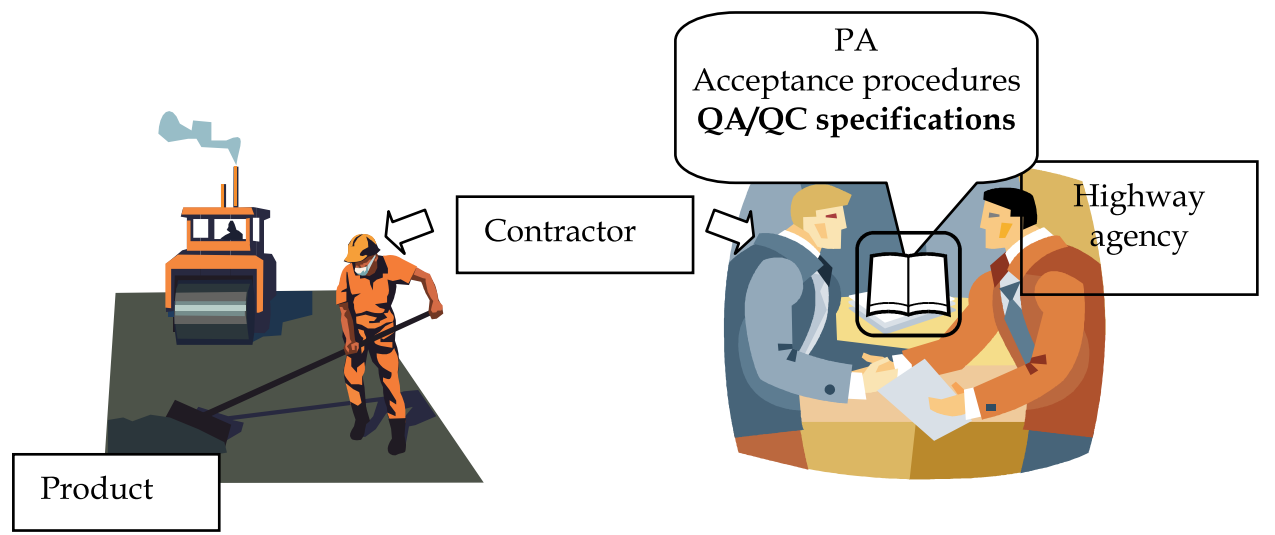

Fig. 1. Contractor vs. agency relationship.

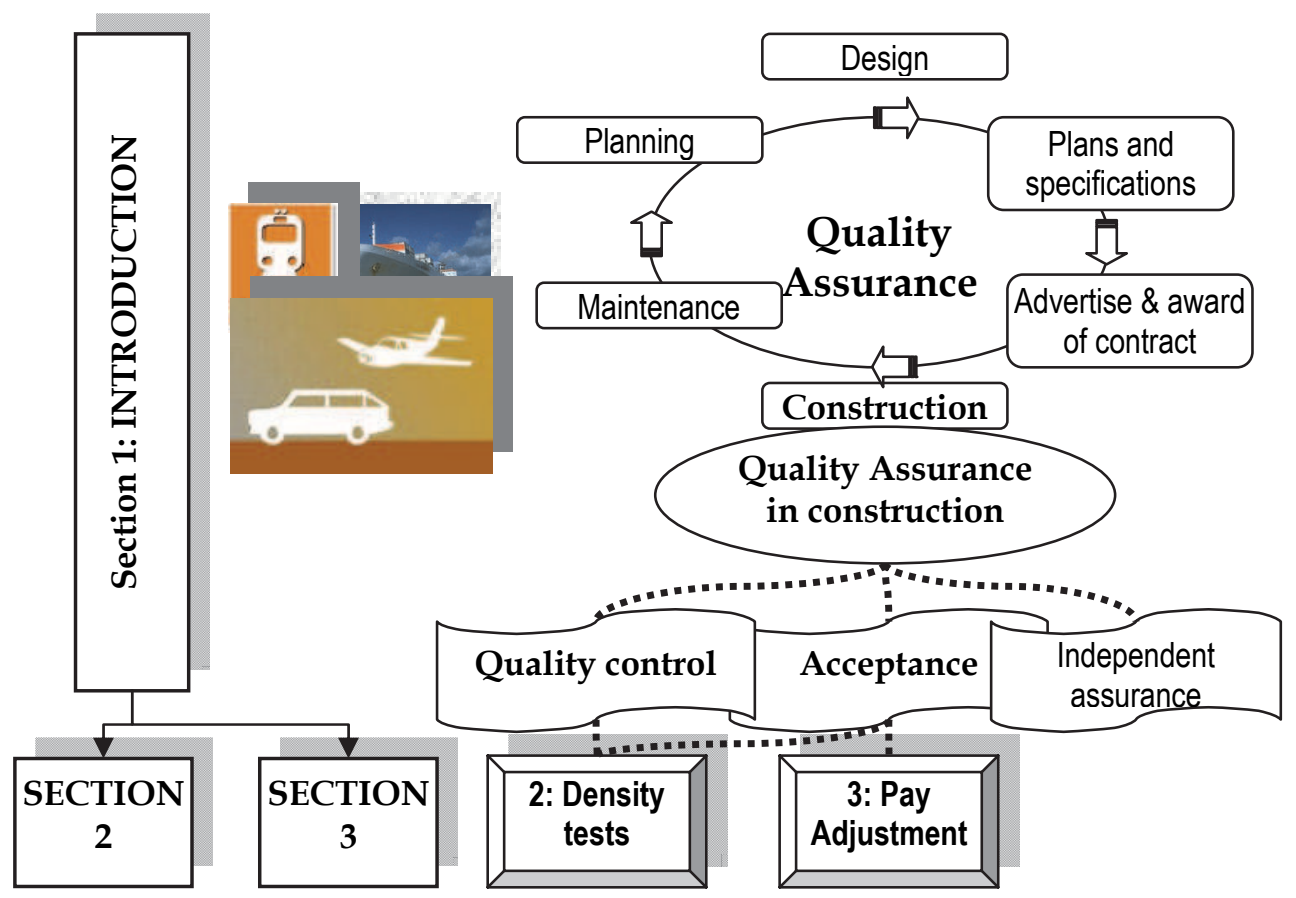

Fig. 2. Conceptual framework of the chapter.

The highway agency's responsibility is to either accept or reject the final product or to apply a price adjustment (PA) commensurate with the degree of compliance with the specifications. In practice, current specifications are neither solely "materials and methods" nor "end result." (Burati et al., 2003). Quality assurance specifications (a.k.a. QA/QC specifications or QC/QA specifications) are a combination of end result specifications and 
materials and methods specifications. QA specification consists of two separate functions, i.e. quality control or process control, and acceptance. As for the development of QC procedures and requirements, the QC procedures and requirements are made up of two parts: the QC requirements (tests to be performed, minimum frequency, qualified laboratories) and the quality characteristics to be measured. For HMAC (hot mix asphalt concrete, or HMA), typical quality characteristics that may be tested for QC include aggregate quality, density (see next section), gradation of critical sieve sizes, plant and discharge temperatures, degree of aggregate coating, moisture content of fine aggregate and/or of finished mix. For PCC (Portland cement concrete), typical quality characteristics that are tested for QC include aggregate quality, gradation of critical sieve sizes, air content, water-cement ratio, mix temperature, slump. Note that three different subjects can carry out the acceptance testing: contractor, agency, third part. The agency: i) may decide to do (itself) the acceptance testing; ii) may assign the testing to the contractor; iii) may have a combination of agency and contractor acceptance testing; iv) or may require a third part to do the testing. In Italy, acceptance testing is usually carried out by a third part, following "general" and "special" Contract specifications (Capitolato special CIRS, Capitolato speciale prestazionale ANAS, etc.). Figure 2 illustrates the conceptual framework of the chapter.

\section{Density}

By referring to density (more technically: bulk specific gravity and air voids content), this is a very crucial factor for $\mathrm{QC} / \mathrm{QA}$ procedures used to evaluate contract specifications. Indeed, the life cycle of hot mix asphalt (HMA) depends on the material density. Bulk specific gravity, $\mathrm{Gmb}$, measures the specific gravity of a compacted hot mix asphalt sample (core or in-lab compacted). Life cycle costs, contract requirements, and QC/QA procedures are all modeled as functions of the effective $\mathrm{Gmb}$ properties resulting from suitable design and construction techniques and by application of appropriate boundary conditions. A variety of methods for determining (in laboratory or on site) Gmb are available (dimensional, AASHTO T 269-EN 12697-6:2003; parafilm, ASTM D 1188; vacuum sealing principle, ASTM D 6752; paraffin coated, BU N40-1973, AASHTO T 275-A, EN 12697-6:2003; saturated Surface Dry, AASHTO T 166, ASTM D 2726, EN 12697-6:2003; non-nuclear portable device, ASTM D 7113, AASHTO TP68). In the vacuum sealing method (VSD), specimen volume is determined by a vacuum chamber that shrink-wraps the specimen in a high quality plastic bag. Surface texture effects can be appreciable, and are accounted for in by the shrink-wrap process. Archimedes' principle is then applied. The dimensional method uses height, diameter, and width measurements to estimate the volume. Surface irregularities (i.e., the rough surface texture of a typical specimen) can introduce inaccuracies, because, in practice, an "osculatory" volume is computed. The parameter $\mathrm{P}$ is a density estimate derived from measurements of a non-nuclear portable device, collected at the tested surface (Williams, 2008; Megali et al., 2010; Rao et al., 2007; Kvasnak et al., 2007; Romero, 2002; Sargand et al., 2005; TransTech, 2003; Gamache, 2004, 2005; Praticò et al, 2009; Praticò et al, 2009a; Praticò and Moro, 2011; Alvarez et al, 2010). In non-nuclear portable device measurements, an electrical current is transmitted from a transmitter through the asphalt concrete pavement at a given location and is detected by the receiver. Note that the current cannot flow through the isolation ring. The impedance (ohm) is measured, and the dielectric constant (dimensionless) is derived. The dielectric constant of the HMA is used to estimate the density. The dielectric constant depends on the HMA composition in that it is derived from the dielectric constants of air $(\sim 1)$ and bitumen \& 
aggregates (5-6). Water and moisture, if present, strongly influence the dielectric constant estimate because the dielectric constant of water approximately 80 . Densities measured in the laboratory (dimensional, parafilm, vacuum sealing principle, paraffin coated, saturated surface dry), when contract specifications are well-defined, are quite reliable and accurate but are obtained very slowly. On-site measurements (non-nuclear portable device) are made using non-nuclear portable devices and result often biased and unreliable. Researchers have attempted to find correlations between the results obtained using different procedures (Brown et al., 2004; Cooley et al., 2002; Crouch et al., 2003; Mohammad et al., 2005; Montepara \& Virgili, 1996; Spellerberg \& Savage, 2004; Williams et al., 2005; Megali et al., 2009). Studies have been carried out in order to propose a theoretical framework for interpreting in-lab and on-site measurements and in the aim of proposing strategies for using non-nuclear portable devices in QC/QA (Megali et al., 2010). A decrease in porosity (or effective porosity) yielded in-lab specific gravities that converged. In contrast, due to the high dielectric constant of water the divergence of in-site measures was observed. The ranking among procedures was the following: GmbSSD > GmbFIN > GmbCOR > GmbFILM > GmbDIM. Furthermore the ranking did not depend on core diameter (Praticò and Moro, 2011b). From a practical standpoint, two strategies were proposed for estimating the density of an asphalt sample: i) consideration of both $\mathrm{W}$ (water content) and $\mathrm{P}$ (density measured through non-nuclear portable devices) in an estimate for the effective porosity, which is the most crucial parameter for quality control evaluation; ii) consideration of both $\mathrm{W}$ and $\mathrm{P}$ in an estimate of density. In (Praticò and Moro, 2011), two equations were proposed for practical applications:

$$
\begin{gathered}
G_{m b C O R}=a P+b W+c \\
n_{e f f}=d P+e W+f
\end{gathered}
$$

where $\mathrm{a}=0.914, \mathrm{~b}=-0.007, \mathrm{c}=0.303, \mathrm{~d}=-56.673, \mathrm{e}=0.420, \mathrm{f}=128.698$ (coefficients are casespecific).

\section{Acceptance procedures}

This section deals with acceptance procedures. Premises (\$3.1) illustrate how acceptance procedures can be carried out, the main indicators which are used and what are the main issues. Afterwards, section 3.2 (model) describes a model for the derivation of the price adjustment (PA) based on life cycle cost analysis. Due to the need of considering surface properties, section 3.3 addresses life expectancy of surface properties (skid resistance, texture, surface wear, drainability, acoustic performance). Bulk properties still remain the key-factor in determining the expected life of the as-constructed pavement. To this end, section 3.4 deals with several tools for the determination of the expected life of a pavement through empirical to rational models. Section 3.5 presents an example of application and provides other references. Main findings are summarized in section 3.6.

\subsection{Premises and symbols}

In the aim of providing a useful indicator for acceptance procedures, from each quality characteristic the corresponding value of quality measure is derived (Burati et al., 2003; Leahy et al., 2009). Quality measure is any one of several means that have been established to quantify quality. Some examples of quality measures are the mean, the standard deviation, the percent defective, the percent within limits, the average absolute deviation, 
and the quality index. Note that it is required to determine specification limits (USL, upper specification limit, and LSL, lower specification limit), and to decide on AQL (Acceptable quality level) and RQL (Rejectable quality level). USL and LSL are the limiting values placed on a quality characteristic, while AQL and RQL refer to the quality measure and are respectively the minimum level of actual quality at which the material or construction can be considered fully acceptable (for that quality characteristic) and that maximum level of actual quality at which the material or construction can be considered unacceptable (rejectable). Specification limits and quality levels are basic inputs to decide pay relationships. Performance-related pay, incentive/disincentive, minimum pay provisions, remove/replace provisions, retest provisions are examples of pay relationships. At the present several classes of models for acceptance procedures depending on input parameters and underlying principle can be listed (Praticò, 2007; Praticò et al, 2008; Praticò et al, 2010a; 2010b; Praticò et al, 2011a): 1) IRI-type models (where IRI stands for International Roughness Index) and average-type models; 2) PD-type models (where PD stands for Percent Defective); 3) LCCA based models (where LCCA stands for Life Cycle Cost Analysis). IRI-type models are based on roughness indicators, as synthetically expressive of the quality of the work and of the related costs (for example the Profile Index (PI), the International Roughness Index (IRI), etc.. In this case the Pay Adjustment (PA) is often empirically determined on the basis of the Pay Factor (PF). PF (and the payment to the contractor) decreases as IRI increases. In the average-based models (see for example typical Italian contracts such as CIRS and ANAS 2008), the pay adjustment (or/and its specific value, $\mathrm{PA} / \mathrm{C}=\mathrm{PA}^{*}$ ) usually depends on the difference (DI), for the given $\mathrm{j}$-th quality characteristic, between the average $\left(\mathrm{x}_{\mathrm{AC}}\right)$ and the design value $\left(\mathrm{x}_{\mathrm{AD}}\right)$. Sometimes the percent difference is used $\left(\%, \mathrm{PDI}=\left(\mathrm{x}_{\mathrm{AC}}-\mathrm{x}_{\mathrm{AD}}\right) / \mathrm{x}_{\mathrm{AD}}\right)$ or its difference from a threshold. It results $\mathrm{PA}=\mathrm{abs}(\mathrm{DI}) \mathrm{k}$ (where abs(DI) indicates the absolute value of DI, while $\mathrm{k}$ usually ranges from 0.3 to 3 and the overall PA is the sum of the PAs of the single quality characteristics. For example, for a SFC (side force coefficient) of 36 instead of 40 , it results $\mathrm{PDI}=10 \%$ and $\mathrm{PA}=10 \cdot 0.5=5 \%$. Note that these models are cumulative and only penalties are involved (no bonuses). Thickness, HMA moduli, pavement bearing, surface properties (such as SFC and sand height, $\mathrm{SH}$ ) are usually the main quality characteristics which are considered. In PDtype models asphalt content, grading, mix in-place density, air voids, Marshall resistance, and/or thickness are often used (Deacon et al., 1997; Epps et al., 1999; Khaled, 2003; Burati, 2005; Hughes et al., 2005). In this case the PA is often (but not always) computed by taking into account the percentage within the limits (PWL), with particular probabilistic hypotheses in order to calibrate agency and contractor risks; for the i-th variable, for a given layer, from the PWLi a percent defective (PDi) and then a pay factor (PFi) are computed; by combining all the PFi a combined pay factor (CPF) is often derived. Given that, by the means of CPF and cost, the Pay Adjustment is computed. LCCA based models are models in which the concept of life cycle cost analysis (as a methodology useful to compare the total user and agency costs of competing project implementation alternatives) is explicit. Therefore, pay adjustment depends on how long the pavement will last (Weed, 2001; Weed \& Tabrizi, 2005; Whiteley et al., 2005). The Pay Factor may be often referred (more or less implicitly) to an expected life. For this reason, the boundary between these different models may be difficult to define. Though many algorithms do exist for assessing pay adjustment, many classes of issues still call for research. Furthermore, note that the real OC curves (Operating Characteristic Curves) and risks will depend on sample size (number of test results used to judge the quality of a lot), lot size and sublot size (sublots are needed in 
order to ensure that the specimens for the sample are obtained from throughout the lot, and are not concentrated in one portion or section of the lot). The operating characteristic (OC) curve is a graphic representation of an acceptance plan that shows the relationship between the actual quality of a lot and either the probability of its acceptance or the probability of its acceptance at various payment levels (for acceptance plans that include pay adjustment provisions). OCs aid in the selection of plans that are effective in reducing risks, because they provide buyer's and seller's risk.

In the abovementioned processes (state-of-the art in the field) the following critical issues can be listed (Praticò, 2008). Problem 1. As is well known (Di Benedetto et al., 1996; Domenichini et al., 1999), all the properties and characteristics influence the real and perceived economic value of the as-constructed pavement at a given time. So, when one characteristic fails, this constitutes a quality assurance problem for the state agency (Burati et al., 2003; Muench \& Mahoney, 2001), and an acceptance plan, with particular acceptance procedures, is needed, in order to estimate a pay adjustment, PA. The use of road surface condition measurements for the acceptance of roadwork is becoming more and more relevant (Boscaino and Praticò, 2001; Boscaino et al, 2005) and calls for a synergistic approach. Problem 2. Can a friction course be treated as the remaining layers in estimating pay adjustment? In other terms, how can pay adjustment be estimated when both surface and mechanical defects are involved? Problem 3. Is it possible to apply life cycle cost analysis when both surface and mechanical performance are involved? Problem 4. Attention is often entirely focused on the quality of single asphalt layers, without any systemic consideration of the quality of the whole multilayer during the life cycle. However, it must be observed that the influence of the bottom layers on the performance of a multilayer can strongly modify both failure typology and pavement expected life. Problem 5. Percentage of defects or average values? Is there a connection between models based on percent defective and model/procedures based on the consideration of average values? Is there the potential for a synergetic consideration of both position and dispersion? Problem 6. Is there a relationship between the position of the mean respect to the limits and the value of the percent of defects? Probably yes, but it depends on the single type of set data (standard deviation, asymmetry, kurtosis, or in the simplest case on standard deviation). Many uncertainties in this field call for further research (Uddin et al, 2011). Problem 7. Given that performance are usually related to averages and not to percent defective, is it possible to relate pavement performance and PDs (percentage of defects)? Problem 8 . The logic of percent defective is usually linked to pay factors and a composite pay factor must be considered. A possibility is to have a correlation between the different factors and the expected life of the pavement. But how much logical and exhaustive can be such procedures? Problem 9. Is it possible a synergetic consideration of defects and delays in pay adjustment models? Problem 10. A drawback of the method of percent defects is the impossibility for taking into account the extended service life due to the surplus in some of the quality indicators (for example thickness), even if other defects are detected. In other terms, PDs are defined positive. Is there any possibility to correct this shortcoming within the framework of the PD-models? Problem 11. Another problem does occur when one tries to apply the concept of percent defective to Open Graded Friction Courses or Porous European Mixes. In fact, in these cases, the quality indicators used in PD evaluation (thickness and air voids) seem not to provide a logical estimate of expected life (included the surface performance). This fact is due also to the uncertainties in the field of the 


\begin{tabular}{|c|c|}
\hline$\tau, \tau \tau$ & $\tau$ refers to each periodical effect on friction $(F) ; \tau \tau=\max \tau$ \\
\hline$\alpha, \beta, \chi$ & real numbers, coefficients \\
\hline$\varphi_{\mathrm{i}}$ & i-th phase of the i-th periodical effect on friction $(\mathrm{F})$ \\
\hline $\mathrm{a}, \mathrm{a}_{\mathrm{i}, \mathrm{a}} \mathrm{a}_{\mathrm{B}}$ & $\begin{array}{l}\text { structural layer coefficients; i refers to i-th layer and B refers to the Bearing } \\
\text { component }\end{array}$ \\
\hline B & "bearing" component of the pavement \\
\hline $\mathrm{BPN}$ & British Pendulum Number \\
\hline $\begin{array}{l}\mathrm{C}_{\mathrm{B}}, \mathrm{C}_{\mathrm{S}} \mathrm{C}_{\mathrm{DP}} \mathrm{C}_{\mathrm{i}} \\
\mathrm{C}_{1 \mathrm{~B}} \% \mathrm{C}_{\mathrm{B}}\end{array}$ & $\begin{array}{l}\text { Present Costs, referred to " } \mathrm{B} \text { " characteristics, to " } \mathrm{S} \text { " ones, to } \mathrm{DP} \text {, to the } \mathrm{i} \text {-th layer, to } \\
\text { the } 1^{\text {st }} \text { layer of the " } \mathrm{B} \text { " component, to " } \mathrm{B} \text { " characteristics as a percent of } \mathrm{C}_{\mathrm{DP}} \text {, } \\
\text { respectively. }\end{array}$ \\
\hline CBR & California Bearing Ratio \\
\hline $\mathrm{CP}$ & as-Constructed Pavement, actual pavement constructed by the contractor \\
\hline $\mathrm{CPF}$ & Combined Pay Factor \\
\hline $\mathrm{CT}$ & equivalent Cumulative Traffic \\
\hline $\mathrm{D}$ & $\begin{array}{l}\text { Design life of the as-Designed Pavement; also called initial design life, it is the } \\
\text { amount of time for which the chosen pavement design is expected to carry the traffic } \\
\text { loads without the application of a global rehabilitation. }\end{array}$ \\
\hline$\overline{\mathrm{DFC}}$ & Dense-graded Friction Course \\
\hline $\mathrm{DP}$ & as-Designed Pavement; desired pavement, as defined by the agency (buyer) \\
\hline$\delta_{\mathrm{AC}, \mathrm{I}}, \delta_{\mathrm{AD}, \mathrm{j}}$ & Parameters which take into account for successive resurfacings. \\
\hline $\mathrm{E}, \mathrm{EB}, \mathrm{ES}$ & $\begin{array}{l}\text { Expected life of the } \mathrm{CP} \text {, general, for only B component, for only } \mathrm{S} \text { component, } \\
\text { respectively }\end{array}$ \\
\hline ESALs & Equivalent single Axes Loads \\
\hline EXPLIF & Expected life \\
\hline $\mathrm{f}_{1} \mathrm{f}_{3}$ & $\begin{array}{l}\text { real numbers, ratio between } C_{2} \text { and } C_{1}(f) \text {, and ratio between } C_{3} \text { and } C_{1}(f 3) \text {, } \\
\text { respectively }\end{array}$ \\
\hline $\mathrm{F}_{1}, \mathrm{~F}_{2}, \mathrm{~F}_{3}, \mathrm{~F}$ & Coefficients $\mathrm{F}_{\mathrm{i}}$ in the formula of the friction $\mathrm{F}$ \\
\hline fre $_{i}$ & i-th frequency (formula for skid resistance dependence on time) \\
\hline $\mathrm{G}_{0}, . ., \mathrm{G}_{3}$ & Real coefficients in the recipe of the expected life (Burati et al, 2003) \\
\hline $\mathrm{h}$ & real number, ratio between $\mathrm{t}_{1 \mathrm{~B}}$ and $\mathrm{t}_{2}$ \\
\hline I & Indicator, for example percolation speed or drainability \\
\hline INF, INT & Inflation rate and interest rate, respectively \\
\hline IRI & International Roughness Index \\
\hline M1B, M1 & $\begin{array}{l}\text { Moduli, respectively, of the first layer of DP- B component and of the first layer of } \\
\text { the DP }\end{array}$ \\
\hline MS & Marshall Stability \\
\hline $\mathrm{N}, \mathrm{n}$ & Number of layers (above the subgrade) total (N) and to resurface/construct (n) \\
\hline NDT & Non Destructive Test \\
\hline $\mathrm{O}, \mathrm{O}_{\mathrm{DP}}, \mathrm{O}_{\mathrm{CP}}$ & $\begin{array}{l}\text { Expected life of successive resurfacing/reconstruction, general, of } \mathrm{DP} \text {, of } \mathrm{CP} \text {, } \\
\text { respectively }\end{array}$ \\
\hline OGFC & Open Graded Friction Course \\
\hline $\mathrm{P}$ & Pavement \\
\hline $\begin{array}{l}\text { PA, PAB, } \\
\text { PAs, PA\%, } \\
\text { PA\%(1L),.. }\end{array}$ & $\begin{array}{l}\text { Pay Adjustments; PA is the total one; B and D mean referred to B or S, respectively; } \\
\% \text { :expressed in percentage, i.e. referred to CDP; }(1 \mathrm{~L}) \text { : referred to one layer }(1 \mathrm{~L}) \text { or } \\
\text { more }(2 \mathrm{~L} \text {, etc.) }\end{array}$ \\
\hline $\mathrm{PD}_{\mathrm{V}}, \mathrm{PD}_{\mathrm{T}}$ & Percent Defective (PD) referred to air voids and to thickness respectively. \\
\hline PEM & Porous European Mixes \\
\hline PF & Pay Factor \\
\hline PI & Profile Index (a roughness indicator) \\
\hline PM & Preventive Maintenance \\
\hline
\end{tabular}




\begin{tabular}{|l|l|}
\hline PWL & Percentage Within Limits \\
\hline PWL & Percentage Within Limits \\
\hline REH & Rehabilitation \\
\hline S & supplementary component of the pavement. It hasn't bearing properties. \\
\hline SFC & Side Force Coefficient \\
\hline$t_{i} t_{1 B}$ & $\begin{array}{l}\text { Thickness of the i-th layer of DP and of the first layer of the bearing component of } \\
\text { DP }\end{array}$ \\
\hline$T_{j}$ & expected life of the j-th supplementary characteristic \\
\hline$U C S$ & Unconfined Compressive Strength -7 day break \\
\hline$Y, Y^{*}$ & Years (real number) and time in years to reach a quasi-constant friction, respectively \\
\hline
\end{tabular}

Table 1. List of symbols and acronyms.

correlations among air voids, moduli and expected life. Problem 12. Can base and subgrade be part of the considered pavement system in such algorithms? Problem 13. The density and volumetrics of as-built pavements is a vital part of QC/QA procedures.

Expected life, infrastructure management and pay adjustment strongly depend on air voids content, especially when bituminous mixes are involved. Despite this measurement process is affected by several classes of uncertainties and many issues still call for further research: influence of core diameter, reliability of non-destructive testing, etc. Table 1 lists the main symbols used in this section.

\subsection{Model}

This section deals with model development. Equations 3-13, Fig.3, Table 1 summarize the derivation of the algorithms. Note that the algorithm here presented overcomes and refines the previous formula as stated in (Praticò, 2007) and was successively updated (Praticò et al, 2010a; Praticò et al, 2010b; Praticò et al, 2011). In summary, the model allows to estimate the pay adjustment on the basis of how long the pavement (considered in all its "qualities") will perform adequately. In order to introduce the model, let DP be the as-designed pavement and $\mathrm{CP}$ be the as-constructed pavement (symbols are listed in table 1). The main inputs of the model are costs and expected lives, while the output is the Pay Adjustment, PA (negative if a penalty is provided). It is well known that the friction course has supplementary characteristics (friction, fire resistance, etc., Praticò et al, 2010c). Therefore, every pavement $\mathrm{P}$ (both $\mathrm{DP}$ and $\mathrm{CP}$, for example) can be divided into two main "components": Bearing characteristics, B, and Supplementary characteristics, S. By comparing, separately, the Bearing characteristics (B, addressing substantially moduli, Poisson coefficients and thicknesses) of the as-Designed Pavement (DP) and of the asConstructed Pavement $(\mathrm{CP})$, the Pay Adjustment $\mathrm{PA}_{\mathrm{B}}$ is estimated (where the subscript $\mathrm{B}$ means that PA is referred to the bearing characteristics). Similarly, by comparing the Supplementary characteristics (S) of as-designed (DP) and of the as-constructed pavement $(\mathrm{CP})$, the pay Adjustment $\mathrm{PA}_{\mathrm{S}}$ is estimated:

$$
\begin{gathered}
P=B+S \\
P A=P_{B}+P_{S}
\end{gathered}
$$

where PAs refers to $S, P A_{B}$ to $B$, and PA to all the non-conformities. To estimate PAs and $\mathrm{PA}_{\mathrm{B}}$, it is necessary to analyze the costs of the pavement during its life. Let $\mathrm{N}$ be the total layers of the as-Designed Pavement (above the subgrade) and let $\mathrm{n}$ be the layers to be 
resurfaced (or reconstructed, if base layers are involved): thus $n \leq N$. Each of the $n$ layers has a contract cost (i.e. present cost of the as-Designed Pavement, in $\left.€ / \mathrm{m}^{2}\right)$ equal to $C_{i}(i=1,2$, .. $\mathrm{n}$, from the surface towards the subgrade), then the relative cost $C_{D P}$ of the as-Designed Pavement can be expressed as follows:

$$
\begin{gathered}
\mathrm{C}_{\mathrm{DP}}=\mathrm{C}_{1}+\mathrm{C}_{2}+\ldots+\mathrm{C}_{\mathrm{n}} . \\
C_{D P}=C_{S}+C_{B}
\end{gathered}
$$

where $C_{S}$ and $C_{B}$ are respectively the cost of the $S$ component (supplementary) and of the $B$ component of the as-designed pavement. The first layer of $B$ will have a present cost $C_{1 B}$ (where $\mathrm{C}$ stands for cost, 1 for $1^{\text {st }}$ layer, B for bearing component of the pavement) and a thickness $\mathrm{t}_{1 \mathrm{~B}}$ (in order to permit to $\mathrm{B}$ to last for $\mathrm{D}$ years). Thus:

$$
\begin{aligned}
& C_{B}=C_{1 B}+C_{2}+\ldots+C_{n} . \\
& C_{S}=C_{D P}-C_{B}=C_{1}-C_{1 B}
\end{aligned}
$$

where $C_{1 B}$, referred to the first layer of the $B$ component (which is intrinsically designed only to have mechanical properties), is generally lower than $C_{1}$. Let INT and INF be the long-term annual interest rate and inflation rate respectively, given in decimal form (typically 0.08 and 0.04 ). The Rate $\mathrm{R}$ is so defined:

$$
R=(1+I N F) \cdot(1+I N T)^{-1} .
$$

For the as-Designed Pavement, let Design life (D) be the expected life in years of the B component and $D_{S}$ of the $S$ component. For the as-Constructed Pavement, let $E_{B}$ be the expected life of the $\mathrm{B}$ component and let $\mathrm{E}_{\mathrm{S}}$ be the expected life of the $\mathrm{S}$ component. In practice, $E_{S}$ can be interpreted as the minimum expected life (years) for supplementary characteristics (where $\mathrm{j}$ represents a given supplementary characteristic):

$$
E S=\min [E S i], i=1,2, \ldots, k
$$

where $\mathrm{ES}_{\mathrm{i}}$ is the expected life of the i-th supplementary characteristic. Note that, in order to consider the right number of resurfacing processes the parameters $\delta\left(\delta_{\mathrm{AC}}\right.$ and $\left.\delta_{\mathrm{AD}}\right)$ can be introduced, where, for example, $a=1, m=1, n=20000, \tau=0.05$, $t=E B-E S-D S$ :

$$
\delta=a \cdot\left(1+m \cdot e^{-t / \tau}\right) \cdot\left(1+n \cdot e^{-t / \tau}\right)^{-1} .
$$

In practice, for $\mathrm{t}=\mathrm{EB}-\mathrm{ES}-\mathrm{DS}=0$ or negative, $\delta$ approaches 0 , while for EB-ES-DS $>1$ it approaches 1 . Note that in a first analysis of the problem $\delta$ can be negleted. Let us introduce the concept of expected life (years) of successive resurfacing or reconstruction (typically 10 years). For the as-Designed Pavement (DP) let ODP be this "successive" expected life, both for B (bearing) and S (supplementary). For the as-Constructed Pavement (CP) let $\mathrm{O}_{\mathrm{CP}}$ be this "successive" expected life, both for B (bearing) and S (supplementary). The reason for separating the concept of $\mathrm{O}$ into two different concepts $\mathrm{O}_{\mathrm{DP}}$ and $\mathrm{O}_{\mathrm{CP}}$ is that the actual expected life of a resurfacing / reconstruction depends also on the part of the pavement notresurfaced. For example, it is possible that, after reconstruction, a subgrade weaker than that set out in contract causes a lower expected life of the surfacing, or that a base stronger then that set out in contract causes a greater one. Given the above facts, it is possible to demonstrate the following (see table 1): 


$$
\begin{gathered}
\mathbf{P A} \cong \mathrm{C}_{\mathrm{S}} \cdot\left(\mathrm{R}^{\mathrm{DS}}-\mathrm{R}^{\mathrm{ES}}\right)+\boldsymbol{\delta}_{\mathrm{AC}} \cdot \mathrm{C}_{\mathrm{S}} \cdot\left[-\left(\mathrm{R}^{\mathrm{ES}}+\mathrm{DS}\right)\right]+\delta_{\mathrm{AD}} \cdot \mathrm{C}_{\mathrm{S}} \cdot\left[\mathrm{R}^{2 \mathrm{DS}}\right]+\left(\mathrm{C}_{S}\right) \cdot\left\{\left[\left(\mathrm{R}^{\mathrm{D}}\right)\right) /\left(1-\mathrm{R}^{\mathrm{ODP}}\right)\right]-\left[\left(\mathrm{R}^{\mathrm{EB}}\right)\right) /(1- \\
\left.\left.\mathrm{ROCP})]\}+\left(\mathrm{C}_{\mathrm{B}}\right) \cdot\left\{\left[\left(\mathrm{R}^{\mathrm{D}}\right)\right) /\left(1-\mathrm{R}^{\mathrm{ODP}}\right)\right]-\left[\left(\mathrm{R}^{\mathrm{EB}}\right)\right) /\left(1-\mathrm{R}^{\mathrm{OCP}}\right)\right]\right\} \cong \\
\left.\left.\cong \mathrm{C}_{S} \cdot\left(\mathrm{R}^{\mathrm{DS}}-\mathrm{R}^{\mathrm{ES}}\right)+\left(\mathrm{C}_{\mathrm{S}}\right) \cdot\left\{\left[\left(\mathrm{R}^{\mathrm{D}}\right)\right) /\left(1-\mathrm{R}^{\mathrm{ODP}}\right)\right]-\left[\left(\mathrm{R}^{\mathrm{EB}}\right)\right) /\left(1-\mathrm{R}^{\mathrm{OCP}}\right)\right]\right\}+\left(\mathrm{C}_{\mathrm{B}}\right) \cdot\left\{\left[\left(\mathrm{R}^{\mathrm{D}}\right)\right) /\left(1-\mathrm{R}^{\mathrm{ODP}}\right)\right]- \\
\left.\left.\left[\left(\mathrm{R}^{\mathrm{EB}}\right)\right) /\left(1-\mathrm{R}^{\mathrm{OCP}}\right)\right]\right\}
\end{gathered}
$$

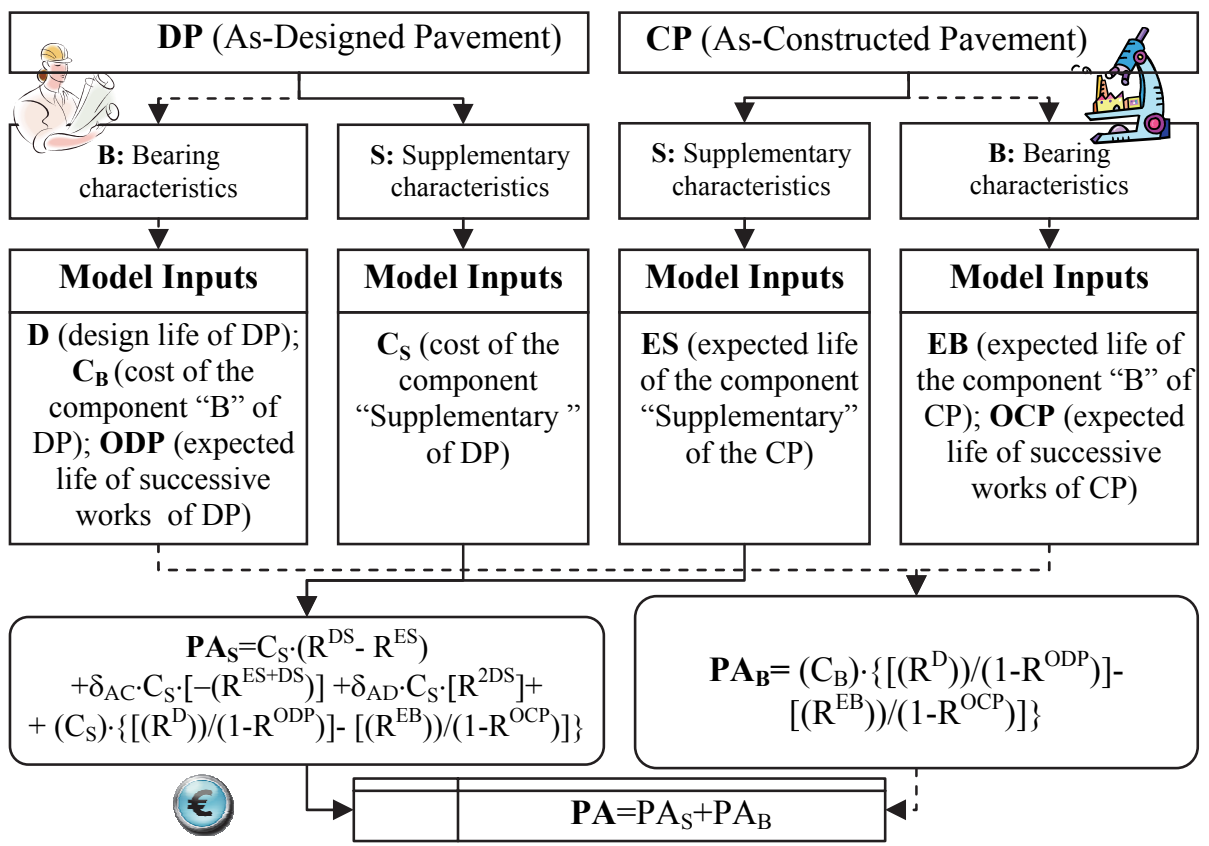

Fig. 3. A synthesis of the model (symbols are listed above).

The term containing $C_{B}$ is the $P A_{B}$, while $P A_{S}$ is given by the sum of the three terms containing $C_{S}$. Note that, when $\mathrm{D}_{S}=\mathrm{E}_{S}, \mathrm{E}_{\mathrm{B}}=\mathrm{E}, \mathrm{C}_{\mathrm{S}}+\mathrm{C}_{\mathrm{B}}=\mathrm{C}, \mathrm{O}_{\mathrm{DP}}=\mathrm{O}_{\mathrm{CP}}=\mathrm{O}\left(\delta_{\mathrm{AD}}=\delta_{\mathrm{AD}}=0\right)$, it follows (as in Burati et al, 2003; Weeds, 2001):

$$
\left.P A=(C) \cdot\left[\left(R^{D}-R^{E}\right)\right) /\left(1-R^{O}\right)\right]
$$

Table 2 illustrates expenditure flows. In order to test the validity of the hypotheses and the effectiveness of the method the following focal points can be focused:

i) In the case of an as-constructed pavement capable of withstanding the design loading, there is only a pay adjustment for non-conformities of supplementary characteristics:

or if

$$
\text { if } D=E_{B} \text { and } O_{D P}=O_{C P} \text {, it is } P A_{B}=0
$$

$$
E_{S}=0, E_{B}=D \rightarrow \infty, O_{D P}=O_{C P}, P A \rightarrow-C_{S} ;
$$

ii) The model is conceived for an expected life of the supplementary component less than that of the bearing component (as-constructed pavement); this limitation is quite obvious and agrees with the state of the art of pavement constructions. The equations system must contain also this equation: 


$$
E_{S} \leq E_{B} ;
$$

iii) As a consequence of the previous point, when the expected life of resurfacing/reconstruction is equal for both the as-Designed and the as-Constructed Pavement, if the expected life of the $\mathrm{S}$ component is greater than that of the B component, then the pay adjustment can be computed by the above-mentioned Ref.Eq. after (Weed, 2001):

$$
\text { if } O_{D P}=O_{C P} \text { and } E_{S}>E_{B} \text {, it is } P A=C_{D P} \cdot\left(R^{D}-R^{E}\right) \cdot\left(1-R^{O}\right)^{-1}
$$

iv) The pay adjustment must be compatible with the cost of the layers to resurface; from this another equation to be included in the equation system is derived. This equation originates from an intrinsic limitation of the model (in common with the previous model (Weed, 2001]); for example for $\mathrm{DB}=20, \mathrm{E}_{\mathrm{B}}=0, \mathrm{O}_{\mathrm{DP}}=\mathrm{O}_{\mathrm{CP}}=10, \mathrm{ES}=\mathrm{DS}$, it is $\mathrm{PA} \cong-1.7 \cdot \mathrm{C}_{\mathrm{DP}}$ (which is inconsistent); the new model agrees with common sense if, when $\mathrm{E}_{\mathrm{B}}=0$, one puts also $\mathrm{DB} \rightarrow \infty$ and $\mathrm{O} \rightarrow \infty$, or/and with $\mathrm{D}=\mathrm{O}$. This supplementary equation is:

$$
P A \geq-C_{D P}
$$

vi) PA is substantially dependent on $\mathrm{D}-\mathrm{E}$ (with $\mathrm{E}=\mathrm{EB}=\mathrm{ES}$ and $\mathrm{O}=\mathrm{OCP}=\mathrm{ODP}$ ); it may be approximated, for example, by linear or quadratic relations:

$$
\begin{gathered}
P A \cdot\left(1-R^{O}\right) \cdot C_{D P^{-1}}=-0.02414284 \cdot(D-E) \\
P A \cdot\left(1-R^{O}\right) \cdot C_{D P^{-1}}=-0.00049374 \cdot(D-E)^{2}-0.0164080 \cdot(D-E)-0.00202513
\end{gathered}
$$

vii) $\mathrm{PA}$ is substantially dependent on $\mathrm{OCP}-\mathrm{ODP}$; for $\mathrm{D}=20$, with $\mathrm{E}=\mathrm{EB}=\mathrm{ES}=15$, it may be approximated, for example, by this linear relation:

$$
\text { PA. } \mathrm{CDP}^{-1}=-0.1601 \cdot(\mathrm{OCP}-\mathrm{ODP})-0.3753
$$

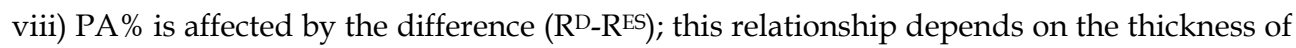
resurfacing/reconstruction; if $\mathrm{f}_{3}=\mathrm{C}_{3} / \mathrm{C}_{1}$, with $\mathrm{f}=\mathrm{C}_{2} / \mathrm{C}_{1}, \mathrm{OCP}=\mathrm{ODP}=\mathrm{O}, \mathrm{D}=\mathrm{EB}$, and $\mathrm{n}$ is the number of layers resurfaced:

$$
\begin{aligned}
& P A \%=(1-f h) \cdot\left(1+f+f_{3}\right)^{-1} \cdot(R D-R E S), \text { for } n=3 \\
& P A \%=(1-f h) \cdot(1+f)^{-1} \cdot\left(R^{D}-R E S\right), \text { for } n=2 \\
& P A \%=(1-f h) \cdot(R D-R E S), \text { for } n=1 \text {, where }(1-f h)>(1-f h) \cdot(1+f)-1>(1-f h) \cdot\left(1+f+f_{3}\right)^{-1}
\end{aligned}
$$

\subsection{Life expectancy of surface properties}

This section deals with the estimate of the life expectancy for the different surface properties (see Figs 4-8, Tabs 2 and 3, equations 25-36 ). The author is aware that, if inadequately used, even the new model could cause misevaluations(Praticò, 2007). Some tools to optimize the estimate process are proposed below. The estimate of ES (as a minimum life expectancy for the various supplementary characteristics) can be obtained from quality control/assurance tests, if the time-dependence of the supplementary characteristics, for given traffic, is predictable. There are many effects and related indicators that can be considered eligible as supplementary characteristics (AA.VV., 2005): drainagebility, friction (polishing), noise, texture, splash \& spray, raveling, reflectivity, chemical spill tolerance, faulting (difference in 


\begin{tabular}{|c|c|c|c|c|}
\hline \multicolumn{2}{|c|}{$\mathrm{AD}$, As-designed pavement } & \multicolumn{2}{|c|}{ AC, As-constructed pavement } & AD vs. AC \\
\hline Times & Expenditure & Times & Expenditure & Pay Adjustment \\
\hline$D S$ & $C_{S} \cdot\left(R^{D S}\right)$ & $E S$ & $C_{S} \cdot\left(R^{E S}\right)$ & $C_{S} \cdot\left(R^{D S}\right)-C_{S} \cdot(R E S)$ \\
\hline $2 D S$ & $\delta_{A D} \cdot C_{S} \cdot R^{2 D S}$ & $E S+D S$ & $\delta_{A C} \cdot C_{S} \cdot\left[\left(R^{E S+D S}\right)\right]$ & $\delta \cdot C_{S} \cdot\left[(R E S+D S)-R^{2 D S}\right]$ \\
\hline$D B$ & $\left(C_{B}+C_{S}\right) \cdot\left(R^{D B}\right)$ & $E B$ & $\left(C_{B}+C_{S}\right) \cdot(R E B)$ & $\left(C_{B}+C_{S}\right) \cdot\left(R^{D B}-R E B\right)$ \\
\hline$D B+O_{D P}$ & $\left(C_{B}+C_{S}\right) \cdot(R D B+O D P)$ & $E B+O_{C P}$ & $\left(C_{B}+C_{S}\right) \cdot(R E B+O C P)$ & $\left(C_{B}+C_{S}\right) \cdot(R D B+O D P-R E B+O C P)$ \\
\hline$D B+2 \cdot O_{D P}$ & $\left(C_{B}+C_{S}\right) \cdot\left(R^{D B+2 . O D P}\right)$ & $E B+2 \cdot O_{C P}$ & $\left(C_{B}+C_{S}\right) \cdot(R E B+2 O C P)$ & $\begin{array}{c}\left(C_{B}+C_{S}\right) \cdot\left(R^{D B+2 . O D P_{-}}\right. \\
R E B+2 O C P) \\
\end{array}$ \\
\hline$D B+n \cdot O_{D P}$ & $\left(C_{B}+C_{S}\right) \cdot\left(R^{D B+n O D P}\right)$ & $E B+n \cdot O_{C P}$ & $\left(C_{B}+C_{S}\right) \cdot(R E B+n O C P)$ & $\begin{array}{c}\left(C_{B}+C_{S}\right) \cdot\left(R^{D B+n O D P}-\right. \\
\left.R^{E B+n O C P}\right) \\
\end{array}$ \\
\hline Sum & $\begin{array}{c}C_{S} \cdot(R D S) \\
+\left(C_{B}+C_{S}\right) \cdot\left(R^{D B}\right) /(1- \\
\left.R^{O D P}\right)\end{array}$ & & $\begin{array}{c}C_{S} \cdot\left(R^{E S}\right) \\
+\left(C_{B}+C_{S}\right) \cdot\left(R^{E B}\right) /(1- \\
\left.R^{O C P}\right)\end{array}$ & $\begin{array}{c}C_{S} \cdot(R D S-R E S) \\
+\delta_{A C} \cdot C_{S} \cdot\left[-\left(R^{E S+D S}\right)\right]+ \\
\delta_{A D} \cdot C_{S} \cdot\left[R^{2 D S}\right]+ \\
\left(C_{B}+C_{S}\right) \cdot\left\{\left[\left(R^{D B}\right)\right) /(1-\right. \\
\left.\left.\left.\left.R^{O D P}\right)\right]-\left[\left(R^{E B}\right)\right) /\left(1-R^{O C P}\right)\right]\right\}\end{array}$ \\
\hline
\end{tabular}

Table 1. A synopsis of times and expenditures flows for AD and AC.

elevation across a joint), pitting, resistance to wearing, etc. Let Esi be the expected life in relation to the i-th characteristic. Under these hypotheses, Es will be the minimum value among the Esi. In the light of the above facts, if $i=1$ (for example friction) and the asdesigned target is $\mathrm{q}_{\mathrm{a}}$, while the as-constructed value of friction is $\mathrm{q}_{\mathrm{b}}<\mathrm{q}_{\mathrm{a}}$, in the case of linear law over the time it results: a) expected life of the as-designed friction course: $E S_{a}=\left(T-q_{a}\right) / m$, where $\mathrm{T}$ stands for minimum level and $\mathrm{m}$ is the gradient (negative); $\mathrm{b}$ ) expected life of the as-constructed friction course: $\mathrm{ES}_{\mathrm{b}}=\left(\mathrm{T}-\mathrm{q}_{\mathrm{b}}\right) / \mathrm{m}$, where $\mathrm{T}$ stands for minimum level; $\mathrm{c}$ ) loss of expected life: $E S_{a}-E S_{b}=\left(q_{b}-q_{a}\right) / m$. For example, if $m=-2, T=35, q_{a}=55, q_{b}=45$, it results $E S_{a}-E S_{b}$ $=5$ years.

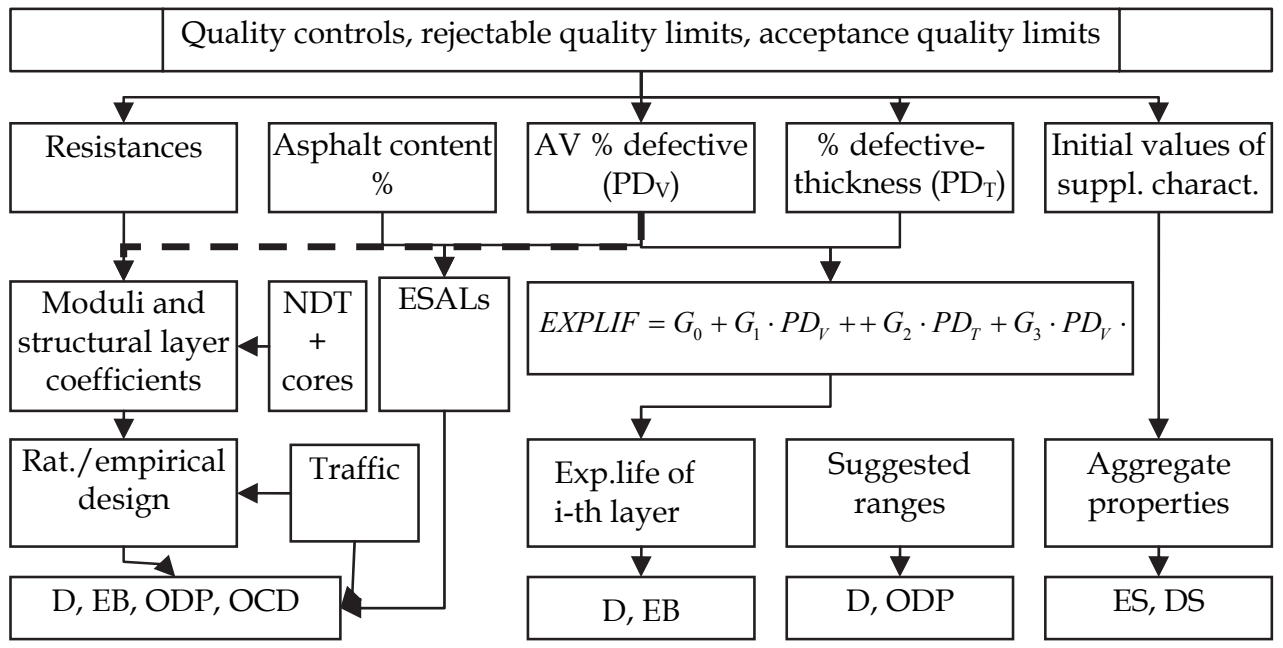

Fig. 4. Expected life: tools to optimize the estimate (symbols are listed in table above). 
As is well known, skid resistance changes over time. Typically it increases in the first two years following construction as the roadway is worn away by traffic and rough aggregate surfaces become exposed, then decreases over the remaining pavement life as aggregates become more polished. Skid resistance is also typically higher in the fall and winter and lower in the spring and summer. This seasonal variation is quite significant and can severely skew skid resistance data if not compensated for. Skid resistance deterioration rate depends on the combination of many factors (aggregate properties and gradation, alignment, detritus build-up, rainfall and traffic characteristics, etc) and this can affect substantially any attempt at prediction and modelling. On the basis of the international literature on this topic the following equation can be here derived for skid resistance $(F)$ drop due to pavement wear:

$$
F=F_{1}+F_{2} \cdot e^{\left[\frac{\gamma}{r^{*}} \cdot \operatorname{Ln}(0.001)\right]}+F_{3} \cdot \prod_{\tau=1}^{\tau \tau} \operatorname{sen}\left(2 \cdot \pi \cdot \text { fre }_{i}-\phi_{i}\right)
$$

where i) Seasonal, monthly, daily effects and variations are considered by the different frequencies ( fre $_{i}$ ) (Diringer and Barros, 1990; Wilson and Kirk, 2005); initial increase is not explicitly considered here; ii) The terminal value $F_{1}$ depends on aggregate shore hardness (both average value and coefficient of variation); this value seems to depend on Polishing Stone Value (PSV, British Standard BS 812, Italian standard CNR BU 140/92) and on Los Angeles (or micro-Deval) (Dupont and Turenq, 1993); both the Los Angeles abrasion number and the PSV, alone, do not correlate well with field performance (Dupont and Turenq, 1993); iii) time in years to reach a quasi-constant friction $\left(\mathrm{Y}^{*}\right)$ can correspond to 2 million cumulative vehicle passes (Diringer and Barros, 1990) and is usually two to four years, depending on traffic and aggregate properties; iv) $\mathrm{F}_{2} \cdot \mathrm{F}_{1^{-1}}$ can be estimated in $0.8 \sim 1.1$ for sedimentary rocks and 0.5 1.4 for igneous rocks (data referred to BPN); v) $\mathrm{F}_{3} \cdot \mathrm{F}_{1}{ }^{-1}$ can be estimated equal to $0.1 \sim 0.3$ (Diringer and Barros, 1990). Figure 5 (left) provides a simplified depiction of these hypotheses on friction time-dependence, where $\mathrm{Y}^{*}=4, \mathrm{~F}_{1}=47 ; \mathrm{F}_{2}=38$, fre $_{1}=1$ year ${ }^{-1}, \varphi_{1}=\varphi_{2}=0$; fre $_{2}=4$ year $^{-1}, \mathrm{~F}_{3} \cdot \mathrm{F}_{1}{ }^{-1}=0.22$; dotted curve refers to fre ${ }_{2}=0$. Figure 5 (right) shows time-dependence for two friction indicators (initial increase is not represented (Brosseaud and Roche, 1997; Kokkalis and Panagouli, 1998). A possible relationship between SFC (Side Friction Coefficient, range 0-1) and SN (Skid Number, range 0-1) (Ullidtz, 1987) is as follows (see figure 5):

$$
S F C=-0.014+1.516 S N
$$

The minimum value of SFC over the time can be also estimated through the following equation (see figure 6):

$$
\text { Min SFC }=0.024-0.663^{*} 10^{\wedge}-4 Q C V+0.01 P S V
$$

where QCV is the number of commercial vehicles/lane/day, PSV is the Polishing Stone Value (Ullidtz, 1987). For limestone, the decrease of SFC over the time as a function of $\mathrm{N}$ (number of heavy vehicle equivalents in millions) and SFCi (initial value of SFC) can be expressed as (see figure7):

$$
\triangle S F C=-0.48 N^{0.373}(S F C i-3)
$$

while for basalt as (figure 7): 


$$
\triangle S F C=-0.30 N^{0.503}\left(S F C_{i}-3\right)
$$

(Flintsch et al, 2001) proposed the following model:

$$
\begin{gathered}
S N(64)_{S}=26.865+2.079 \cdot \text { Binder }+1.601 \cdot P P 200+1.03 \cdot V T M \\
S N(64)_{R}=104.211-4.356 \cdot N M S+0.1833 \cdot V T M
\end{gathered}
$$

where $\mathrm{SN}(64) \mathrm{S}$ stands for Skid Number measured at $64 \mathrm{Km} / \mathrm{h}$ for smooth tires, Binder stands for binder code (-1 for PG 64-22, 0 for PG 70-22, 1 for PG 76-22), PP200 is the percentage of material passing the \#200 sieve, VTM represents the total voids in the mix, $\mathrm{SN}(64)_{\mathrm{R}}$ stands for Skid Number measured at $64 \mathrm{Km} / \mathrm{h}$ for ribbed ( R) tires, NMS is the Nominal Maximum Size. Note that the model after Flintsch et alia refers to the starting point of diagrams (asconstructed value). In particular, for Binder $=-1, \mathrm{NMS}=12.5, \mathrm{PP} 200=5, \mathrm{VTM}=20$ it results $\mathrm{SN} 64_{\mathrm{S}}=\mathrm{SN} 64_{\mathrm{R}}=53$ and for Binder $=-1, \mathrm{NMS}=19, \mathrm{PP} 200=5, \mathrm{VTM}=6$, it results $\mathrm{SN} 64_{\mathrm{S}}=39$ and $\mathrm{SN} 64_{R}=23$. As for texture, (Flintsch et al, 2001) proposed the following model:

$$
M P D=-2.896+0.2993 N M S+0.0698 V M A
$$

where MPD stands for Mean Profile Depth, NMS for Nominal Maximum Size and VMA for Voids in Mineral Aggregates. Note that in this case the law doesn't provide the variation over the time. Another model for texture depth was developed (Arnold et al, 2005) according to the following algorithm:

$$
\mathrm{MPD}=\mathrm{k} 1-\mathrm{k} 2 \cdot \log (\mathrm{N}),
$$

where $k 1$ and $k 2$ are constants and $N$ is number of wheel passes. The constants $k_{1}$ and $k_{2}$ in the equation (the Patrick equation) have been calculated for two different cases (see figure 7). The Surface wear due to the combined action of salt and traffic can be estimated through the following model (Ullidtz, 1987, Praticò et al, 2010):

$$
R D W=2.48 \cdot 10^{-5} \cdot \mathrm{PASS}^{1.02} \cdot \mathrm{CW}-0.46 \cdot \mathrm{S}^{1.22} \cdot \mathrm{SALT}^{0.32}
$$

Where RDW is the rut depth due to studded tires in mm, PASS is the number of vehicles with studded tires in one direction expressed in thousand, $\mathrm{CW}$ is the carriageway width in $\mathrm{m}, \mathrm{S}$ is the vehicle speed in $\mathrm{Km} / \mathrm{h}$, and SALT is a variable for salting (2 salted, 1 unsalted, see figure). Based on other authors (Smith, 1979), with studded tires in the range $7-23 \%$, concrete pavement wear can be considered as follows:

$$
P W \approx 0,5^{*} Y
$$

Where PW is the wear in mm, while Y stands for number of years. Also drainability values depend on the chosen indicator (Praticò and Moro, 2007a, 2008a). On the basis of the international literature on this topic, a typical curve for drainability is as follows (where I is drainability indicator, $Y$ stands for years, $\alpha$ and $\chi$ are positive and $\beta$ is negative; PEM indicates porous European mixes; EM: emergency lane):

$$
I=\alpha \cdot e^{\beta \cdot Y}+\chi
$$

It is important to note that, although some of these estimates may be considered approximate, all the inputs may be "conditioned" by the same methodology and the PA 
formula is strongly dependent on the differences $\mathrm{D}-\mathrm{E}$ and $\mathrm{O}_{\mathrm{CP}}-\mathrm{O}_{\mathrm{DP}}$. This can help to reduce the possible conflicts between contractor and buyer without using simple but empirical formulas and models not well-grounded in logic.

\begin{tabular}{|c|c|c|c|c|c|c|}
\hline Pavement & $\alpha$ & $\beta$ & $\chi$ & Indicator $I$ & $I$ Range & Y Range (years) \\
\hline PEM & 0.469 & -0.778 & 0.862 & Percolation speed $(\mathrm{cm} / \mathrm{s})$ & $0.79 \sim 1.5$ & $0 \sim 3$ \\
\hline PEM & 0.449 & -2.435 & 0.795 & Percolation speed $(\mathrm{cm} / \mathrm{s})$ & $0.57 \sim 1.6$ & $0 \sim 3$ \\
\hline PEM & 1.049 & -0.778 & 0.248 & Permeability $(\mathrm{cm} / \mathrm{s})$ & $0.3 \sim 1.3$ & $0 \sim 3.75$ \\
\hline PEM - EL & 1.119 & -1.312 & 0.168 & Permeability $(\mathrm{cm} / \mathrm{s})$ & $0.15 \sim 1.3$ & $0 \sim 3.75$ \\
\hline
\end{tabular}

Table 2. Time-dependence of drainability (example).
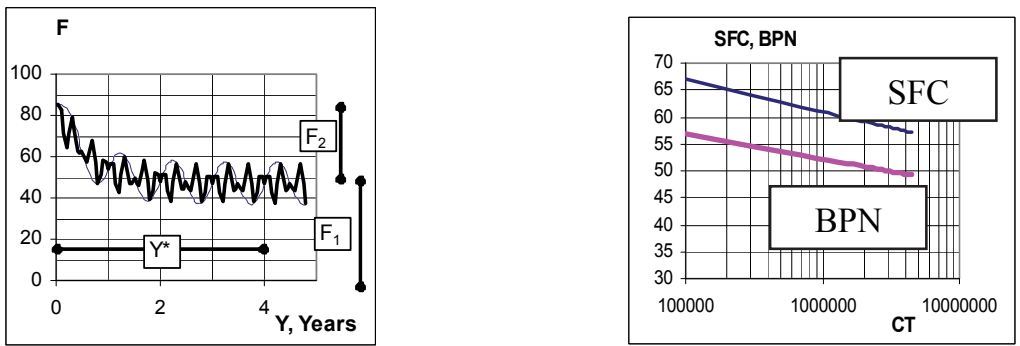

Note: F: Friction indicator; SFC: Side Friction Coefficient; BPN: British Pendulum Number

Fig. 5. Skid resistance $(\mathrm{F}=\mathrm{BPN})$ vs. time (Years) and skid resistance $(\mathrm{SFC}, \mathrm{BPN})$ versus equivalent Cumulative Traffic (CT).
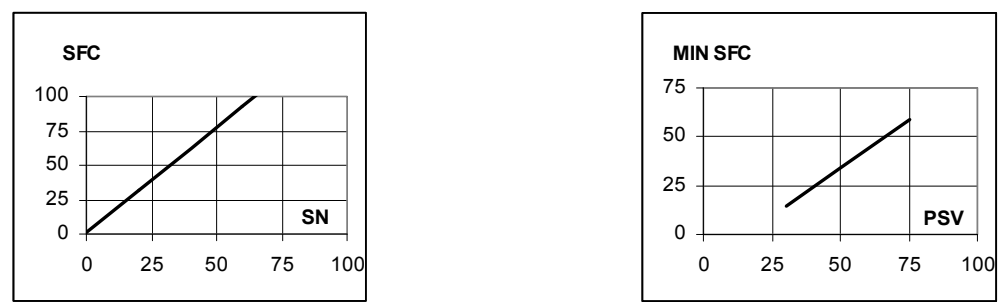

Fig. 6. Example of relationship SN vs. SFC and PSV vs. MINSFC.
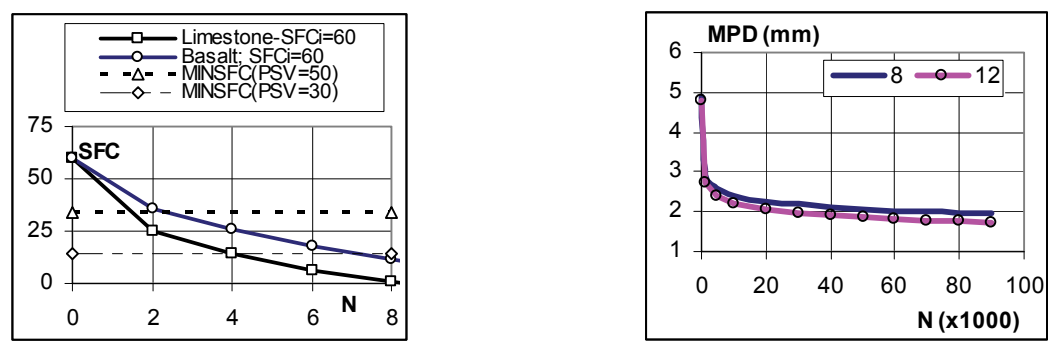

Fig. 7.Example of relationships $\mathrm{N}$ vs. SFC and MPD vs. number of axes. 

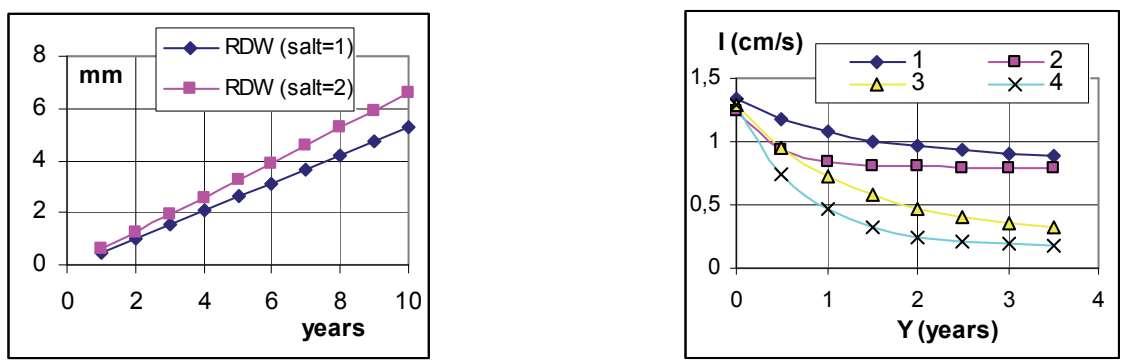

Fig. 8. Example of relationships years vs. wear $(\mathrm{mm})$ or permeability.

As for noise mitigation, based on the international literature the following information is available:

\begin{tabular}{|l|l|l|l|}
\hline Solution & E & IN & FINAL \\
\hline DAC (dense asphalt concrete) & Variable & 0 & -2 \\
\hline PA (porous asphalt) & $10-12$ & 4 & $<3(?)$ \\
\hline TPA (two-layer porous asphalt) & 9 & 6 & 4 \\
\hline SMA-like thin layers & 9.5 & 4.7 & 3 \\
\hline Porous-type thin layers & 8.5 & 5 & 3 \\
\hline $\begin{array}{l}\text { E: Expected lifetime (years); IN: Initial noise reduction (db(A)); FINAL: Final/minimum } \\
\text { noise reduction (db(A)) }\end{array}$
\end{tabular}

Table 3. Duration of noise mitigation (SPB method).

\subsection{Life expectancy of bulk properties}

Both for unbound and HMA/PCC layers, volumetrics, mechanistic performance and related indicators are often correlated and vary over the time. Equations 37-38, Figs 9-13, Tables 4 and 5 summarize several practical relationships. In the M-E PDG, the HMA layer modulus is characterized using the dynamic modulus (or backcalulated modulus from FWD data). In more detail, the dynamic modulus at a given loading time and temperature is assumed to be the elastic modulus in the response computation. PCC materials need a static modulus of elasticity adjusted with time. For chemically stabilized materials the elastic modulus or the resilient modulus is needed (lime-stabilized typical value: $45000 \mathrm{psi}$ ). For unbound materials the resilient modulus is needed (39000 psi: very good; 10000psi: very poor). In the AASHTO guide 1993 the structural layer coefficients and the resilient modulus (subgrade) are used. Design life (D) of the as-Designed Pavement (DP), can be estimated from contract specifications. D can also be estimated on the basis of the design report (in which it is usually specified). Empirical or rational design can be used after having estimated structural layer coefficients or moduli from resistance thresholds set out in the contract (Marshall Stability, MS, for surface course, base course and bituminous treated bases, California Bearing Ratio (CBR), for untreated bases or subbases, Unconfined Compressive Strength - 7 day break (UCS) for cement treated bases, (Huang, 2003), see figures 9 to 13); by knowing thickness and traffic loading it is therefore possible to estimate D. Importantly, on the basis of the international literature (Van Til et al, 1972; Gaspard, 2000; Sebesta, 2005) and current practice, the modulus of cement treated bases 
which corresponds to a given laboratory resistance (Unconstrained Compressive Strength - 7-day break) can vary to a great extent in relation to many factors (time from base construction, traffic, subgrade drainage, shrinkage cracks, etc). Figure 9 shows the relationship between resistances and structural layer coefficients according to (Van Til et al, 1972). Note that in the following figures MS indicates Marshall stability, $M$ the modulus, a the structural layer coefficient, UCS is the unconstrained compressive strength- 7 day break, CBR is the california bearing ratio; ESAL indicates equivalent single axle load, $A C$ stands for as-constructed. In principle, $\mathrm{E}_{\mathrm{B}}$, expected life of the bearing component of the as-Constructed Pavement, can be estimated as D (except where D is derived from thresholds in contracts or from design report). Moreover, it must be noted that for the asphalt layers there are empirical formulas that can be used to estimate $\mathrm{D}$ and $\mathrm{E}_{\mathrm{B}}$ in function of Percent Defective of air voids and thickness $\left(\mathrm{PD}_{\mathrm{V}}, \mathrm{PD}_{\mathrm{T}}\right.$, (Burati et al, 2003)), or in function of the air voids and asphalt content of the as-Constructed Pavement. Both for $\mathrm{E}_{\mathrm{B}}$ and $\mathrm{D}$, reliable information can be obtained from Non-Destructive Tests, NDT (e.g. Falling Weight Deflectometer), or / and laboratory tests on cores (resilient moduli test methods AASHTO TP9-94-1B, ASTM D 4123, LTPP P07) (Giannattasio and Pignataro, 1983; Ullidtz, 1987). The estimate of ODP and OCP can be approached by the same methodologies above-mentioned for $\mathrm{D}$ and $\mathrm{E}_{\mathrm{B}}$ respectively (see also tables 4 and 5). All these values can be modified (and costs upgraded) if extended service life gains for preventive maintenance treatment are considered (overband crack filling, crack sealing, single or double chip seal, slurry seal, microsurfacing, ultrathin, hot-mix asphalt overlay, hot-mix asphalt mill and overlay, etc.) and in relation to particular design philosophies.
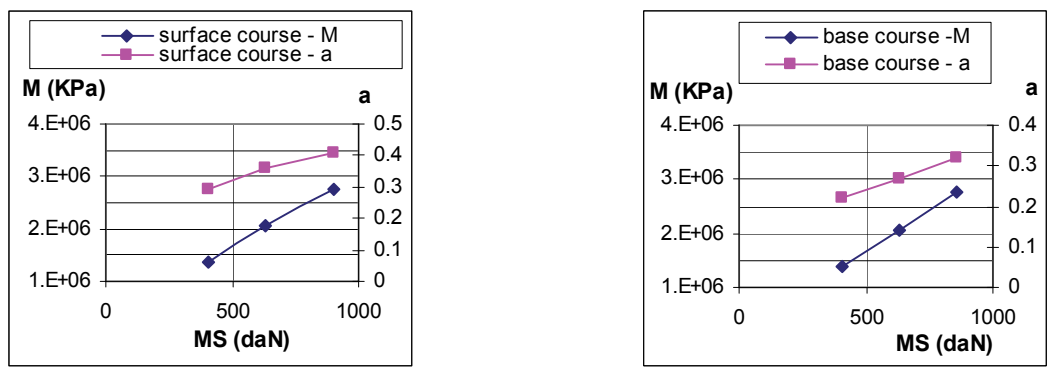

Fig. 9. Example of MS-M-a relationships, for surface courses and base courses. 


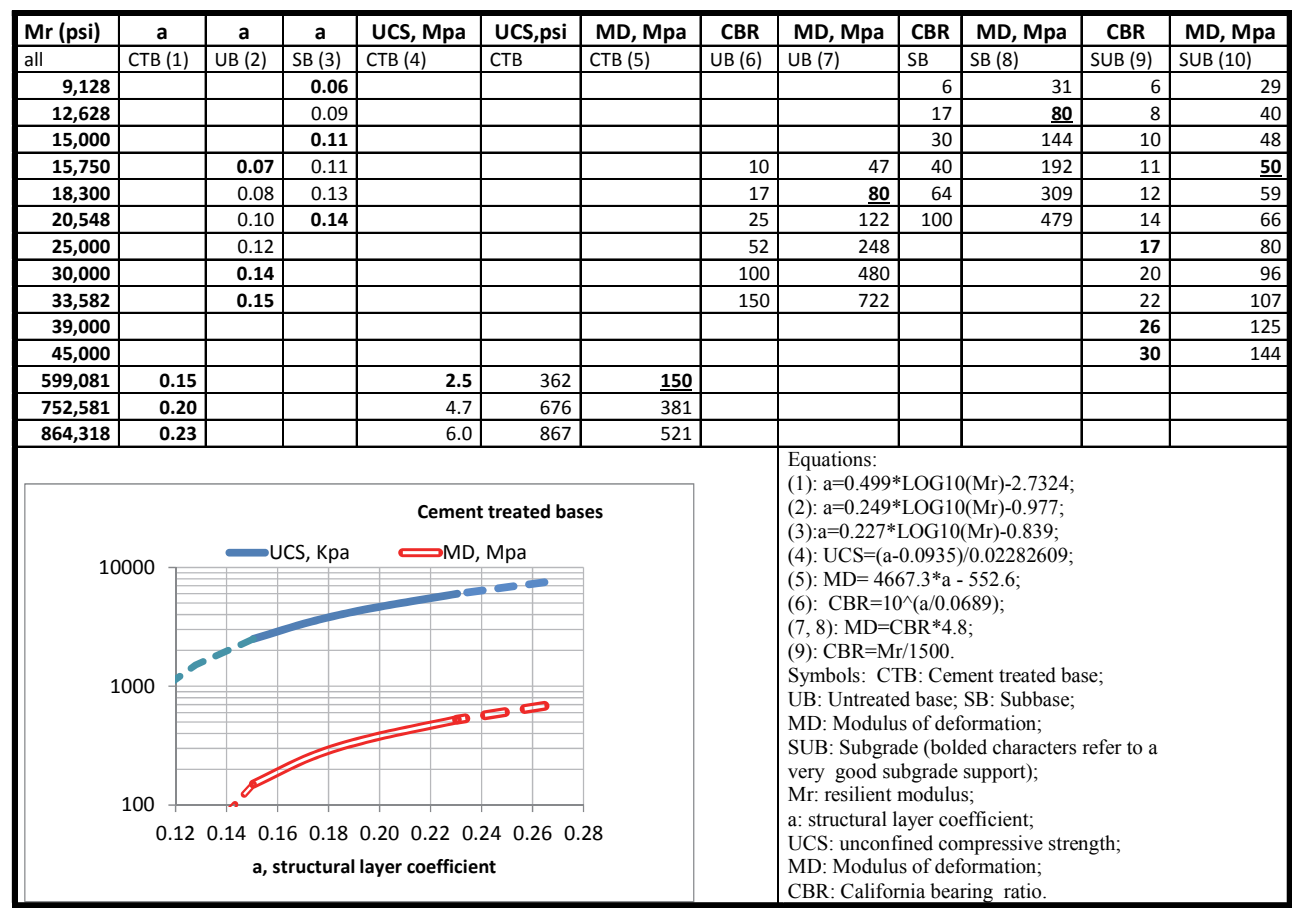

Fig. 10. Cement treated base courses, untreated bases, subbases, subgrades.
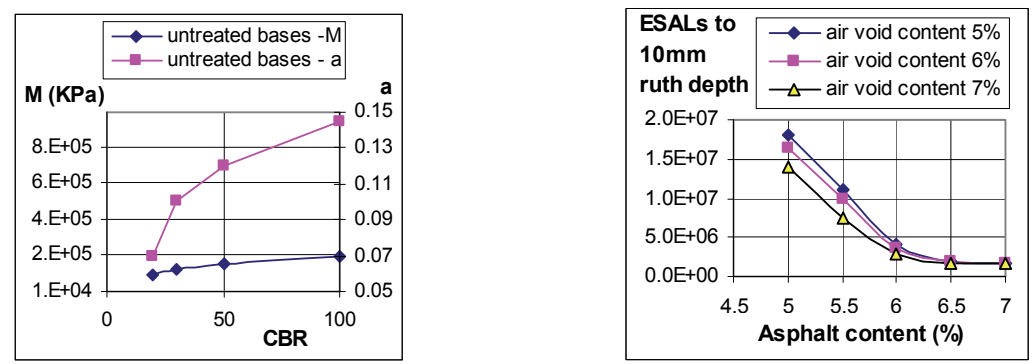

Fig. 11. Left (untreated bases): CBR vs. $M$ and a. Right (surface course - fine gradation): ESALs to 10mm Ruth Depth vs. asphalt content (Epps et al. , 1999). 

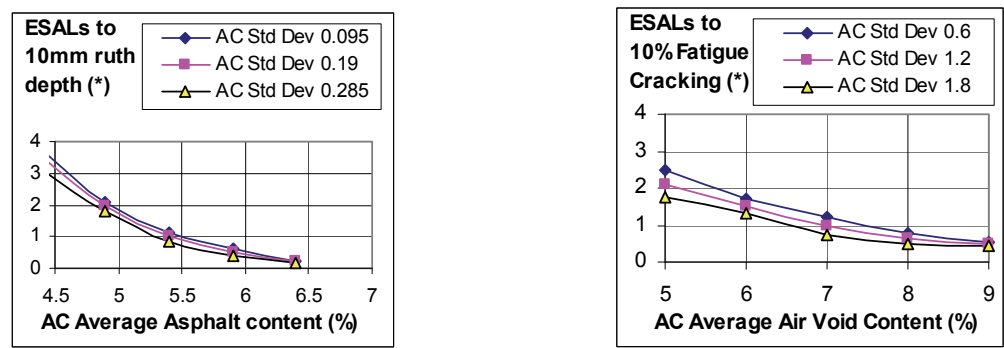

Fig. 12. Left: ESALs to $10 \mathrm{~mm}$ vs. asphalt content. Right: ESALs to $10 \%$ vs. air void content (Surface courses (Epps et al. , 1999)) (*) expressed as multiple of target ESALs.
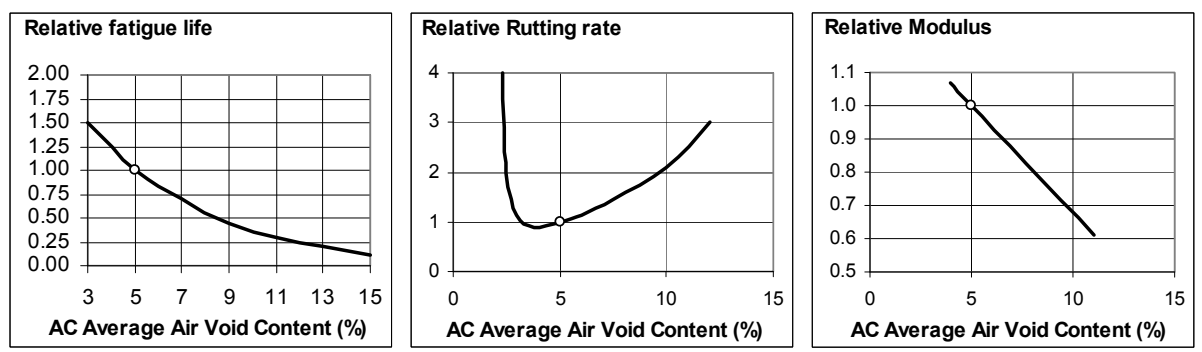

Fig. 13. Air Voids vs. Relative Fatigue Life (left) or Relative Rutting Rate (center) or . Relative Modulus (right) - Surface courses (Austroroads, 1999).

\begin{tabular}{|l|l|l|l|}
\hline $\begin{array}{l}\text { years to } 1^{\text {st }} \\
\text { rehabilitation }(\cong D)\end{array}$ & $\begin{array}{l}\text { years to } 2^{\text {nd }} \\
\text { rehabilitation }(\cong \mathrm{ODP})\end{array}$ & $\begin{array}{l}\text { years to } 3^{\text {rd }} \\
\text { rehabilitation }(\cong \mathrm{ODP})\end{array}$ & $\begin{array}{l}\text { years to } 4^{\text {th }} \\
\text { rehabilitation }(\cong \mathrm{OPP})\end{array}$ \\
\hline $\begin{array}{l}12 \sim 16 \text { (base layer } \\
\text { undrained) } \\
15 \sim 20 \text { (base layer } \\
\text { drained) }\end{array}$ & $\begin{array}{l}12 \sim 16 \text { (full depth mill and } \\
\text { overlay) }\end{array}$ & $\begin{array}{l}10 \sim 12 \text { (mill and } \\
\text { and overlay) } \\
\text { overlay) } \\
\text { overlay) }\end{array}$ & \\
\hline
\end{tabular}

Table 4. Estimates of years to the $\mathrm{n}$-th rehabilitation.

Note that the application of the PA formula depends on the ability to split the surface course into two parts. A tentative method to estimate $t_{1 B}, C_{1 B}, C_{B}$ and $C_{S}$ is to identify the component $\mathrm{B}$ of DP in a pavement with a design life $\mathrm{D}$, but with a different friction course (this time with negligible surface properties, for example just the binder course). In particular, two tentative values of $\mathrm{t}_{1 \mathrm{~B}}$ may be obtained by the following expressions:

$$
t_{1 B} \cdot M_{1 B}^{1 / 3} \simeq t_{1} \cdot M_{1}^{1 / 3} ; \quad t_{1 B} \cdot a_{1 B} \cong t_{1} \cdot a_{1}
$$

where the modulus $\mathrm{M}_{1 \mathrm{~B}}$ of the first layer of the $\mathrm{B}$ component of the as-Designed Pavement can be tentatively identified in $\mathrm{M}_{2}$, the structural layer coefficient $\mathrm{a}_{1 \mathrm{~B}}$ can be considered equal to $\mathrm{a}_{2}$, and the thicknesses $\mathrm{t}_{1}$ and $\mathrm{t}_{2}$ are known. As above-mentioned, $\mathrm{M}_{1}, \mathrm{M}_{2}$ (moduli of the $1^{\text {st }}$ and $2^{\text {nd }}$ layer of the DP) and $\mathrm{a}_{1}, \mathrm{a}_{2}$ (structural layer coefficients of the $1^{\text {st }}$ and $2^{\text {nd }}$ layer of the DP) may be estimated by using correlation charts and algorithms in literature 
references (Van Til et al, 1972; Huang, 2003) in function of the traditional resistance tests. Similarly, $C_{1 B}, C_{B}$ and $C_{S}\left(€ / m^{2}\right)$, for a given $t_{1 B}$, can be easily estimated by comparing the costs of the $1^{\text {st }}$ and $2^{\text {nd }}$ layer of the DP, given that the cost of the unit of volume of the layers $1 \mathrm{~B}$ and 2 of the DP are the same. For example, if $\mathrm{C}_{2}$ and $t_{2}$ are the cost and thickness of the second layer of the as-Designed Pavement respectively, then for $h=0.5, f=0.6$ : if

$$
\begin{gathered}
t_{1 B}=h \cdot t_{2}, C_{2}=f \cdot C_{1}, C_{1 B} \cdot t_{1 B}{ }^{-1}=C_{2} \cdot t_{2}{ }^{-1}\left(€ / m^{3}\right) \Rightarrow C_{1 B}=f \cdot h \cdot C_{1}, C_{S}=C_{1} \cdot(1-f \cdot h) \\
C_{S}=0.7 \cdot C_{1}, \quad C_{1 B}=0.3 C_{1} \quad C_{B}=0.3 \cdot C_{1}+C_{2}+\ldots+C_{n}
\end{gathered}
$$

\begin{tabular}{|c|c|c|c|c|}
\hline \multirow[t]{2}{*}{ Treatment } & \multicolumn{2}{|c|}{$\begin{array}{c}\text { expected Life } \\
\text { (Years, Y) }\end{array}$} & \multirow{2}{*}{$\begin{array}{l}\text { Cost } \\
\left(€ / \mathrm{m}^{2}\right)\end{array}$} & \multirow{2}{*}{$\begin{array}{c}\text { Cost for } \\
\text { year } \\
€ /\left(\mathrm{m}^{2} \cdot \mathrm{Y}\right)\end{array}$} \\
\hline & $\min$ & $\max$ & & \\
\hline Crack seals (PM) & 2 & 3 & 1.7 & 0.66 \\
\hline Fog Seals (PM) & 3 & 4 & 0.8 & 0.24 \\
\hline Slurry seal (PM) & 4 & 9 & 1.5 & 0.23 \\
\hline Microsurfacing (PM) & 5 & 14 & 2.3 & 0.24 \\
\hline Chip seals (PM) & 4 & 6 & 1.3 & 0.26 \\
\hline Thin hot mix overlay (PM/REH) & 2 & 10 & 2.8 & 0.47 \\
\hline HMA- Dense Graded (5cm) (PM/REH)- (ODP $\rightarrow)$ & 5 & 15 & 5.3 & 0.53 \\
\hline $\begin{array}{l}\text { Asph. Rubber Hot Mix - Gap Graded (4-5cm) (PM/REH)- } \\
(\mathrm{ODP} \rightarrow)\end{array}$ & 10 & 20 & 5.9 & 0.40 \\
\hline $37.5 \mathrm{~mm}$ mill+37.5mm overlay $(\mathrm{PM} / \mathrm{REH})-(\mathrm{ODP} \rightarrow)$ & 8 & 12 & 7.2 & 0.72 \\
\hline Milling $(37.5 \mathrm{~mm})+100 \mathrm{~mm}$ overlay $(\mathrm{REH})-(\mathrm{ODP} \rightarrow)$ & 18 & 22 & 9.5 & 0.48 \\
\hline Milling+thick overlay $(75-180 \mathrm{~mm})(\mathrm{REH})-(\mathrm{ODP} \rightarrow)$ & 18 & 25 & 10.9 & 0.51 \\
\hline \multicolumn{5}{|c|}{ Note. PM: Preventive Maintenance treatment; REH: REHabilitation } \\
\hline \multicolumn{5}{|c|}{ After (Moulthrop et al, 1998; Hicks and Epps, 2005; Shober and Friedrichs, 2002) } \\
\hline
\end{tabular}

Table 5. Summary of a variety of maintenance and rehabilitation life expectancy and costs.

\subsection{Experimental application}

An experimental application was performed on a motorway in Southern Italy. Traditional quality characteristics of the mixes, for single lane and given layer, have been organized in function of the progressive abscissa. Many experimental devices were used in order to measure the actual characteristics of the as-constructed pavement. From the comparison between the requirements of the as-designed pavement (DP) and the actual characteristics of the as-constructed pavement $(\mathrm{CP})$ the moduli for $\mathrm{DP}(@ 0)$ and $\mathrm{CP}(@ 0)$ were derived (see table 7). The ratio $t_{1 в} / t_{2}$ was about 0.5 ; asphalt concrete thickness was $27 \mathrm{~cm}$ for DP and about $27-5+3.5=25.5 \mathrm{~cm}$ for the B component of the pavement. Results were obtained by Kenpave $^{\mathrm{TM}}$ [Huang, 2003] and successfully compared with the AASHTO Guide 1993 equation. By analyzing the drainability and friction data, $E_{S}=3$ was estimated, caused by insufficient drainability. Pay adjustments (in absolute and in percentage, as referred to the $\operatorname{cost} \mathrm{C}_{\mathrm{DP}}$ ) are summarized in table 8 . 


\begin{tabular}{|l|l|l|l|l|l|}
\hline & $\mathrm{DP}(@ 0)$ & $\mathrm{DP}, \mathrm{B}(@ 0)$ & $\mathrm{CP}(@ 0)$ & $\mathrm{DP}\left(@ \mathrm{E}_{\mathrm{B}}\right)$ & $\mathrm{CP}\left(@ \mathrm{E}_{\mathrm{B}}\right)$ \\
\hline $\begin{array}{l}\text { Asphalt }(27 \\
\left.\text { or } 25.5^{*} \mathrm{~cm}\right)\end{array}$ & $2.29 \cdot 10^{6}$ & $\begin{array}{l}2.65 \cdot 10^{6} \\
\left.{ }^{*}\right)\end{array}$ & $1.00 \cdot 10^{6}$ & $2.29 \cdot 10^{6}$ & $2.29 \cdot 10^{6}$ \\
\hline $\begin{array}{l}\text { Cement } \\
\text { treated } \\
(20 \mathrm{~cm})\end{array}$ & $1.00 \cdot 10^{6}$ & $1.00 \cdot 10^{6}$ & $1.30 \cdot 10^{6}$ & $0.50 \cdot 10^{6}$ & $0.70 \cdot 10^{6}$ \\
\hline $\begin{array}{l}\text { Subbase + } \\
\text { sub-grade }\end{array}$ & $0.10 \cdot 10^{6}$ & $0.10 \cdot 10^{6}$ & $0.13 \cdot 10^{6}$ & $0.10 \cdot 10^{6}$ & $0.11 \cdot 10^{6}$ \\
\hline Life (years) & $\mathrm{D}=22$ & $\mathrm{D}=22$ & $\mathrm{E}_{\mathrm{B}}=18$ & $\mathrm{O}_{\mathrm{DP}}=12$ & $\mathrm{O}_{\mathrm{CP}}=14$ \\
\hline Output & $\mathrm{D}$ & $\mathrm{t}_{1 \mathrm{~B}} / \mathrm{t}_{2}=0.50$ & $\mathrm{E}_{\mathrm{B}}$ & $\mathrm{O}_{\mathrm{DP}}$ & $\mathrm{O}_{\mathrm{CP}}$ \\
\hline
\end{tabular}

Table 7. Case-history (years are rounded to the nearest integer; moduli in $\mathrm{KPa}$ ).

\begin{tabular}{|c|c|c|c|c|}
\hline \multirow{10}{*}{ 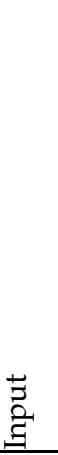 } & INT & 0.08 & $\mathrm{C}_{2}$, asphalt, $€ / \mathrm{m}^{2}$ & 4,25 \\
\hline & INF & 0.04 & $\mathrm{C}_{3}$, asphalt, $€ / \mathrm{m}^{2}$ & 7,27 \\
\hline & $\mathrm{R}$ & 0.963 & Cost of the cement treated, $€ / \mathrm{m}^{2}$ & 6,92 \\
\hline & $\mathrm{D}$ (years) & 22 & Cost of the granular sub-base, $€ / \mathrm{m}^{2}$ & 3,83 \\
\hline & $\mathrm{E}_{\mathrm{B}}$ (years) & 18 & Overall Cost $€ / \mathrm{m}^{2}$ & 29,09 \\
\hline & $E_{S}$ (years) & 3 & Asphalt cost $€ / \mathrm{m}^{2}$ & 18,34 \\
\hline & $\mathrm{O}_{\mathrm{DP}}$ (years) & 12 & $\mathrm{C}_{\mathrm{B}}, € / \mathrm{m}^{2}$ & 13.65 \\
\hline & $\mathrm{O}_{\mathrm{CP}}$ (years) & 14 & $\mathrm{C}_{\mathrm{S}}, € / \mathrm{m}^{2}$ & 4.69 \\
\hline & $t_{1 \mathrm{~B}} / \mathrm{t}_{2}$ & 0,5 & $\mathrm{C}_{\mathrm{B}} \%$ & 74.42 \\
\hline & $\mathrm{C}_{1}$, asphalt, $€ / \mathrm{m}^{2}$ & 6,82 & $\mathrm{CS}_{\mathrm{S}} \%$ & 25.58 \\
\hline \multirow{6}{*}{$\begin{array}{l}\overrightarrow{\vec{z}} \\
\frac{\overrightarrow{2}}{2} \\
0\end{array}$} & \multicolumn{2}{|l|}{$\mathrm{PA}\left(€ / \mathrm{m}^{2}\right)$} & \multicolumn{2}{|l|}{-2.51} \\
\hline & \multicolumn{2}{|l|}{$\mathrm{PA}_{\mathrm{B}}\left(€ / \mathrm{m}^{2}\right)$} & \multicolumn{2}{|l|}{-0.52} \\
\hline & \multicolumn{2}{|l|}{$\mathrm{PA}_{\mathrm{S}}\left(€ / \mathrm{m}^{2}\right)$} & \multicolumn{2}{|l|}{-1.99} \\
\hline & \multicolumn{2}{|l|}{ PA $\%$} & \multicolumn{2}{|l|}{-13.70} \\
\hline & \multicolumn{2}{|l|}{$\mathrm{PA}_{\mathrm{B}} \%$} & \multicolumn{2}{|l|}{-2.85} \\
\hline & \multicolumn{2}{|l|}{$\mathrm{PA}_{\mathrm{S}} \%$} & \multicolumn{2}{|l|}{-10.85} \\
\hline
\end{tabular}

Table 8. PA determination -Inputs and outputs (the percentages are referred to $C_{D P}$ ).

\section{Main findings}

In the light of above facts, the main findings of the study can be summarized in terms of drawbacks and point of strengths. Air void content has a vital role in QC/QA. A decrease in porosity (or effective porosity) yields in-lab specific gravities that converge toward the maximum theoretical specific gravity $\mathrm{G}_{\mathrm{mm}}$ (convergence of in-lab measurements). In contrast, gravities determined through non-nuclear portable devices often increase due to the high dielectric constant of water (divergence of in-site measures).

Uncertainties in the determination of the expected life of the different characteristics and complexity are the main drawbacks of the models of PA based on LCCA. On the contrary, 
though more research is needed, analyses proved that the LCCA-based models are able to give a solution well-grounded in logic, even in cases where supplementary characteristics, such as drainability or friction, may have a premature failure. In particular, when only the bearing characteristics of asphalt layers are considered, analyses proved that the complex model (in which also supplementary characteristics are considered) gives the same solution as an existing model (Weed, 2001). The effectiveness and importance of the complex models increases when thin resurfacing/reconstruction is considered. The conceptual framework of the complex models, finally, has the potential for considering other supplementary characteristics such as for example the albedo. Analyses and experimental applications proved that the complex models quantify the dependence of the pay adjustment on all the layers. Another point of interest is that life expectancy differences govern PA estimates: this can play a key role in reducing possible conflicts between buyer and contractor. Future research will aim to consider the consequences of the new model here set out in terms of relationship between probability of acceptance and expected lives.

\section{References}

Alvarez AE, Epps Martin A, Estakhri C. Internal structure of compacted permeable friction course mixtures. Construction and Building Materials, 24 (2010) 1027-1035.

Arnold G., Steven B., Alabaster D. \& Fussell A. (2005). Effect on Pavement Wear of Increased Mass Limits for Heavy Vehicles - Stage 4 - Land Transport New Zealand Research Report 280.

Austroroads and Australian Asphalt pavement Association, Air voids in asphalt, 1999.

Boscaino, G., Pratico, F.G. , A classification of surface texture indices of pavement surfaces | [Classification et inventaire des indicateurs de la texture superficielle des revêtements des chaussées], 2001, Bulletin des Laboratoires des Ponts et Chaussees (234), pp. 17-34+123+125+127.

Brosseaud Y., Roche J-P (1997). Chantier experimental d'enrobés drainants, Bilan après huit annèes de traffic sur l'A63, Revue Générale des routes et des aerodromes, n.755, pp.47-52.

Brown ER. Hainin MR, Cooley A, Hurley G. Relationship of Air Voids, Lift Thickness, and Permeability in Hot Mix Asphalt Pavements. NCHRP Report 531, National Center for Asphalt Technology-Auburn University, Auburn, AL, Transportation Research Board, Washington, D.C. 2004.

Burati J., L., Weed R. M., Hughes C. S., Hill H. S.(2003). Optimal procedures for quality assurance specifications, Final Report n. FHWA-RD-02-95, Office of research, development, and technology, Federal Highway administration (FHWA - COTR: Peter A. Kopac) - 6300 Georgetown Pike, McLean, VA 22101-2296.

Burati, J., L., Jr (2005). Risks with Multiple Pay Factor Acceptance Plans, TRB 2005 Annual Meeting, January.

Cooley LAJr, Prowell BD, Hainin MR, Buchanan MS, Harrington, J. Bulk specific gravity round-robin using the corelok vacuum sealing device. National Center for Asphalt Technology Report 02-11, FHWA-IF-02-044, November 2002.

Crouch LK, Badoe DA, Cates M, Borden TA, Copeland AR, Walker CT, Dunn T, Maxwell RA, Goodwin WA. Bulk specific gravity of compacted Bituminous mixtures: 
finding a more widely applicable method. Final Report, State of Tennessee, Department of Transportation, July 2003.

Deacon John A., Monismith Carl L., and Harvey John T. (1997). California department of transportation, "Pay factors for asphalt-concrete construction: effect of construction quality on agency costs".

Di Benedetto H. et alia (1996). Mesures in situ et en laboratoire des écoulement dans les BBDr, modélisation et validation, Bulletin des Laboratoires des Ponts et Chaussées, 204.

Diringer K. T., Barros R. T. (1990). Predicting the skid resistance of bituminous pavements through accelerated laboratory testing of aggregates, Surface characteristics of roadways: International research and technologies, ASTM STP 1031, W.E. Meyer and J. Reichert, Eds, ASTM, Philadelphia.

Domenichini L., Fracassa A., La Torre F., Loprencipe G., Ranzo A., Scalamandrè A. (1999). Relationship between Road Surface Characteristics and Noise Emission, $1^{\circ}$ Int.Coll. on Vehicle Tyre Road Interaction, Roma.

Dupont P., Tourenq C. (1993). Granulats et microrugosité, Bull. Liaison Labo. P. et Ch., Ref. 3719 , mai-juin.

Epps J. A. et al. (1999). "The road to performance-related specifications", International Conference on Accelerated Pavement Testing, Reno, NV, October 18-20.

Flintsch G, Al-Qadi I.L., Davis R., McGhee K.K. (2001). Effect of HMA properties on pavement surface characteristics, 2002 FWD Users Group Presentations, Nevada.

Friedrichs D. A., Pavement design and programmino options: european design to maintain only, Wisconsin Department of Transportation Library, USA, 2002.

Gamache RW. FEA guides the way for sensor redesign. Machine Design, April 15, 2004. p. 25.

Gaspard K.J., Evaluation of Cement Treated Base Courses, Technical assistance report Number 001TA, Louisiana transportation research center, Louisiana department of transportation and development, December, 2000.

Giannattasio P., Pignataro P., La caratterizzazione dei conglomerati bituminosi, dati di ingresso per il calcolo delle pavimentazioni, Scuola di specializzazione in infrastrutture aeronautiche, Napoli, 1983.

Huang Y.H. (2003). Pavement Analysis and Design, Pearson Prentice Hall, Upper Saddle River, NJ, USA.

Hughes C.S. et alia (2005). NCHRP Synthesis 346, State Construction Quality Assurance programs, Transportation Research Board, Washington D.C..

Khaled Ksaibati, Ph.D., P.E., Nathan E. Butts (2003). Asphalt pavement quality control/quality assurance programs in the United States, TRB 2003 Annual Meeting .

Kokkalis A. G., Panagouli O. K.(1998). Fractal evaluation of pavement skid resistance variations. II: surface wear, Chaos, solitons \& fractals, Vol.9, 11, pp.1891,1889, Pergamon Press.

Kvasnak AN, Williams C, Ceylan H, Gopalakrishnan K. Investigation of electromagnetic gauges for determining in-place HMA density. IHRB Project TR-547, CTRE Project 
05-233, Final Report, Iowa State University, Ames; Iowa Department of Transportation, 2007.

Leahy et al. Committee on Management of Quality Assurance (A2F03) (2002). Glossary of Highway Quality Assurance terms, Transportation Research Circular number EC037, TRB National research Board, 2101 Constitution Avenue, NW, Washington, DC 20418, April.

Main italian laws and standards concerning pay adjustments (1998-2000). a) L.11.02.94, n. 109; b) L. 18 novembre 1998, n. 415 - c.d. L. Merloni ter; c) Capitolato Speciale d'appalto ANAS 1998 e succ.- artt.12, 13, 19; d)D.P.R. 21.12 .99 n. 554 (Reg. di attuazione); e) Norme tecniche di tipo prestazionale per capitolati speciali d'appalto (CIRS, Centro sperimentale Interuniversitario di Ricerca Stradale), 2000; Capitolato prestazionale ANAS 2008; Capitolato Autostrade.

Megali, G., Cacciola, M., Ammendola, R., Moro, A., Praticò, F.G., Morabito, F.C., Assessing reliability and potentiality of nonnuclear portable devices for asphalt mixture density measurement, 2010, Journal of Materials in Civil Engineering 22 (9), pp. 874-886.

Mohammad LN, Herath A, Wu Zhong, Cooper SA. Comparative study of factors influencing the permeability of hot-mix asphalt mixtures. Volume 74E Electronic Journal 2005, AAPT Publications, 2005.

Montepara A, Virgili A. La determinazione della massa volumica e dei vuoti nei conglomerati bituminosi aperti. Atti Convegno S.I.I.V. Ancona, 1996.

Moulthrop J.S., Hicks G.R., Delaiden J.L., Selecting a flexible pavement preventive maintenance, 1998 Western Pavement maintenance Forum, Sacramento, CA, USA, January, 1998.

Muench, S.T. and Mahoney, J.P.(2001). A Quantification and Evaluation of WSDOT's Hot Mix Asphalt Concrete Statistical Acceptance Specification. WA-RD 517.1. Washington State Department of Transportation, Transportation Center (TRAC). Seattle, WA.

Niagara Peninsula, "Special provisions - contract items", 2004.

Praticò F.G., How should payment adjustments be assessed when both surface and mechanical defects are involved? a synergetic study on theory and experiments, SURF $08-6^{\text {th }}$ Symposium on surface characteristics, Portoroz, Slovenia, 20/22 October -2008 .

Praticò F.G., Quality and timeliness in highway construction contracts: a new acceptance model based on both mechanical and surface performance of flexible pavements, Construction Management and Economics, Volume 25, Issue 3, pages 305 - 313, Routledge - Taylor and Francis 2007, March.

Praticò FG, Moro A, Ammendola R. Modeling HMA Bulk Specific Gravities: A Theoretical and Experimental Investigation. International Journal of Pavement Research and Technology 2/3 (2009) 115-122.

Praticò, F.G., Moro, A , Measurement of air void content in hot mix asphalts: method and core diameter dependence, 2011b, Construction and Building Materials, doi: 10.1016/j.conbuildmat.2011.06.032. 
Praticò FG, Moro A. Permeability and volumetrics of porous asphalt concrete: a theoretical and experimental investigation. International Journal: Road Materials and Pavements Design, Vol. 8 N 4/2007a.

Praticò, F.G., Ammendola, R., Moro, A., Factors affecting the environmental impact of pavement wear, 2010, Transportation Research Part D: Transport and Environment 15 (3), pp. 127-133

Praticò, F.G., Casciano, A., Tramontana, D., Pavement life-cycle cost and asphalt binder quality: Theoretical and experimental investigation, 2011a, Journal of Construction Engineering and Management 137 (2), pp. 99-107

Praticó, F.G., Moro, A., Ammendola, R., Factors affecting variance and bias of non-nuclear density gauges for porous european mixes and dense-graded friction courses, 2009a, Baltic Journal of Road and Bridge Engineering 4 (3), pp. 99-107+Ia+IIA+IIIA.

Praticò, F.G., Moro, A., Ammendola, R., Potential of fire extinguisher powder as a filler in bituminous mixes, 2010c, Journal of Hazardous Materials 173 (1-3), pp. 605-613

Praticò, F.G., Moro, A., Flow of water in rigid solids: Development and experimental validation of models for tests on asphalts, 2008a, Computers and Mathematics with Applications 55 (2), pp. 235-244.

Praticò, F.G., Moro, A., In-lab and on-site measurements of hot mix asphalt density: Convergence and divergence hypotheses, 2011, Construction and Building Materials 25 (2), pp. 1065-1071.

Praticò, F.G., Moro, A., Permeability and volumetrics of porous asphalt concrete: A theoretical and experimental investigation, 2007b, Road Materials and Pavement Design 8 (4), pp. 799-817

Praticò, F.G., Tramontana, D., Casciano, A., Attinà, A. , Geosynthetics and pavement life cycle: An analysis through the M-E PDG, 2010a, Geotechnical Special Publication (207 GSP), pp. 302-309.

Praticò, F.G., Tramontana, D., Casciano, A., Bitumen quality, pavement LCCA and contractor's expectations, 2010b, Geotechnical Special Publication (203 GSP), pp. 523-529

Rao C, Von Quintus HL, Schmitt R. Calibration of Non-nuclear Density Gauge Data for Accurate In-Place Density Prediction. Session 596. 86th TRB annual meeting, Washington D.C., January 2007.

Romero P. Evaluation of Non-Nuclear Gauges to Measure Density of Hot-Mix Asphalt Pavements. Pooled Fund Study, Final Report, The University of Utah Department of Civil and Environmental Engineering July 18, 2002.

Salt (1997). Research on skid resistance at the transport and road research laboratory (1972 to 1977), TRR 622, TRB, Washington, DC.

Sargand SM, Kim Sang-Soo, Farrington SP. Non-Nuclear Density Gauge Comparative Study. Draft Final Report. Ohio Research Institute for Transportation and the Environment, 114 Stocker Center, Ohio University, Athens, OH, 45701-2979, August 2005.

Sebesta S., Use of microcracking to reduce shrinkage cracking in cement treated bases, Transportation Research Board 2005 Annual Meeting, 2005. 
Shober S.F., Friedrichs D.A. (2002). A Pavement Preservation Strategy, Wisconsin Department of ransportation Library, USA.

Siegwart, R. (2001). Indirect Manipulation of a Sphere on a Flat Disk Using Force Information. International Journal of Advanced Robotic Systems, Vol.6, No.4, (December 2009), pp. 12-16, ISSN 1729-8806

Smith R.D. (1979) Pavement wear and studded tire use in Iowa, Final Report, Iowa highway research Board, Project HR-148.

Spellerberg P, Savage D. An investigation of the cause of variation in HMA Bulk Specific Gravity test results using non-absorptive aggregates. National Cooperative Highway Research Program Web Document 66 (Project 9-26 (Phase 2), July 2004.

State of Florida Department of Transportation (2004). Asphalt concrete friction courses, December.

TransTech Systems Inc. Effect of Water and Temperature on Hot Mix Asphalt Density Measurement using Electromagnetic Sensing. TransTech Technical Note 0301, Schenectady, January 15, 2003. Available online:

http://www.transtechsys.com/products/pro_lib_pqi.htm.

Uddin, M., Mohboub, K.C., Goodrum, P.M. (2011). “Effects of Nonnormal Distributions on Highway Construction acceptance Pay Factor Calculations", Journal of Construction Engineering and Management, volume 137, n², pp. 108-118.

Ullidtz, P. (1987). Pavement Analysis. Elsevier, Amsterdam.

Van Til, C.J., McCullough B.F., Vallerga B.A., Hicks R.G., Evaluation of AASHO Interim guides for of pavement structures, NCHRP 128, Highway Research Board, 1972.

Weed Richard M. (2001). "Derivation of equation for cost of premature pavement failure", 80th TRB annual meeting.

Weed Richard M., Kaz Tabrizi , Conceptual framework for pavement smoothness specification, TRB 2005 Annual Meeting, January, 2005.

Western Federal Lands Highway Division FP Specification Change (2004). "Pavement Smoothness/Roughness".

Whiteley Leanne, Susan Tighe, Zhanmin Zhang, Incorporating Variability into Pavement Performance, Life Cycle Cost Analysis and Specification Pay Factors, 84th Annual Meeting - January 9-13, 2005.

Williams SG. Non-Nuclear Methods for HMA Density Measurements. MBTC 2075, Final Report, University of Arkansas, June 2008. 


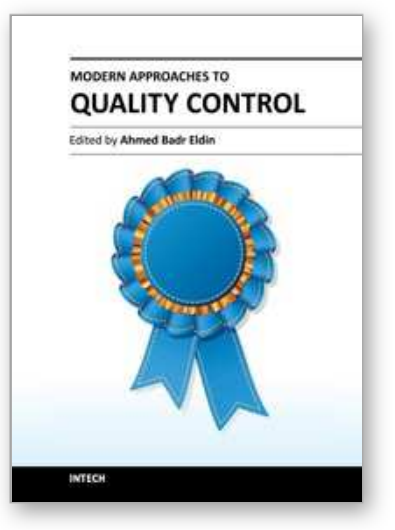

\author{
Modern Approaches To Quality Control \\ Edited by Dr. Ahmed Badr Eldin
}

ISBN 978-953-307-971-4

Hard cover, 538 pages

Publisher InTech

Published online 09, November, 2011

Published in print edition November, 2011

Rapid advance have been made in the last decade in the quality control procedures and techniques, most of the existing books try to cover specific techniques with all of their details. The aim of this book is to demonstrate quality control processes in a variety of areas, ranging from pharmaceutical and medical fields to construction engineering and data quality. A wide range of techniques and procedures have been covered.

\title{
How to reference
}

In order to correctly reference this scholarly work, feel free to copy and paste the following:

Filippo G. Praticó (2011). QA/QC in Transport Infrastructures: Issues and Perspectives, Modern Approaches To Quality Control, Dr. Ahmed Badr Eldin (Ed.), ISBN: 978-953-307-971-4, InTech, Available from: http://www.intechopen.com/books/modern-approaches-to-quality-control/qa-qc-in-transport-infrastructuresissues-and-perspectives

\section{INTECH}

open science | open minds

\author{
InTech Europe \\ University Campus STeP Ri \\ Slavka Krautzeka 83/A \\ 51000 Rijeka, Croatia \\ Phone: +385 (51) 770447 \\ Fax: +385 (51) 686166 \\ www.intechopen.com
}

\author{
InTech China \\ Unit 405, Office Block, Hotel Equatorial Shanghai \\ No.65, Yan An Road (West), Shanghai, 200040, China \\ 中国上海市延安西路65号上海国际贵都大饭店办公楼 405 单元 \\ Phone: +86-21-62489820 \\ Fax: +86-21-62489821
}


(C) 2011 The Author(s). Licensee IntechOpen. This is an open access article distributed under the terms of the Creative Commons Attribution 3.0 License, which permits unrestricted use, distribution, and reproduction in any medium, provided the original work is properly cited. 